\title{
O GOVERNO E A ADMINISTRAÇÃO DO BRASIL SOB OS HABSBURGO E OS PRIMEIROS BRAGANÇA*
}

por

\author{
PEDRO CARDIM
}

Universidade Nova, Lisboa

RESUMEN: La historiografía dedicada al gobierno y a la administración del Brasil en el periodo 1580-1700 ba conocido un desarrollo muy significativo. Además de baberse registrado una interesante discusión conceptual, se asiste a la formulación de una serie de nuevos modelos interpretativos, asi como a la apertura de temas $y$ campos poco o nada explorados. El fin de este artículo es caracterizar esta evolución y llamar la atención sobre este estimulante terreno bistoriográfico en el que, tras décadas de separación, la historia del Antiguo Régimen en América y Europa aparecen cada vez más sintonizadas.

Palabras Clave: Brasil colonial. Historia Atlántica. Gobierno. Administración. Élites luso-brasileñas. Siglos XVI-XVII.

ABSTRACT: The bistoriography dedicated to the government and administration of Brazil in the period 1580-1700 has recently experienced a very significant development. In addition to witnessing an interesting conceptual reconsideration, it has seen the formulation of a series of new interpretative models, as well as the exploration of new or understudied themes and fields. The aim of this article is to characterise this development and call attention to the stimulating historiographical domain in which, after decades of separation, the bistory of the «ancien régime» in Europe and the Americas is increasingly integrated

KEY WORDS: Colonial Brazil. Atlantic History. Government. Administration. Luso-Brazilian elites. Early Modern period.

- Uma primeira versão deste trabalho foi apresentada na École des Hautes Études en Sciences Sociales, Paris, em Maio de 2002. Posteriormente, este estudo foi aprofundado graças ao apoio concedido pelo GRICES (MCES) e pelo CAPES no âmbito do projecto «Colónia e Metrópole: Instituiçōes e Práticas Sociais. Um estudo comparativo». 
O campo de estudos dedicado à história colonial do Brasil conheceu, nos últimos anos, desenvolvimentos muito significativos. Ao mesmo tempo que se procedeu à abertura de novas áreas de trabalho, estabeleceu-se um diálogo crítico com as grandes propostas interpretativas da história brasileira. Como resultado, dispomos hoje de uma imagem verdadeiramente renovada do período compreendido entre o último quartel de Quinhentos e o final do século XVII ${ }^{1}$.

Uma das facetas mais singulares da referida renovação é o facto de ela ter sabido preservar os seus laços com a "grande tradição" da historiografia dedicada ao período dos Habsburgo e dos primeiros Bragança. Assim, a despeito de todas as novidades, continua a notar-se a presença do fundamental legado de Sérgio Buarque de Holanda, de Caio Prado Jr. e, até, da menos consensual obra de Gilberto Freyre. Permanecem igualmente presentes os contributos de Eduardo d'Oliveira França e de Vitorino Magalhães Godinho, ou os trabalhos de Frédéric Mauro e de Fernando Novais.

Não menos relevantes para a renovação deste campo de estudos foram as pesquisas desenvolvidas, desde o final da década de 1960, por Dauril Alden², por A. J. R. Russell-Wood e por Stuart B. Schwartz. Aprofundando linhas de investigação abertas, sobretudo, por Charles R. Boxer ${ }^{3}$, estes e outros investigadores norte-americanos ${ }^{4}$ (assim como alguns estudiosos brasileiros, como foi o caso de Vera Amaral Ferlini ${ }^{5}$ ) exploraram diversos temas da história sócioeconómica do Brasil dos Habsburgo e dos Bragança, assinando, também, alguns estudos fundamentais de história institucional - recorde-se o pioneiro trabalho de Stuart Schwartz sobre o Tribunal da Relação da Bahia ${ }^{6}$, ou o de A. J. R. Russell-Wood sobre a Misericórdia da Bahia ${ }^{7}$. A Stuart Schwartz deve-

I Para uma boa panorâmica desta renovação historiográfica consulte-se, CARDOSO, Ciro F. e VAINFAS, Ronaldo (org.): Os dominios da bistória, Rio de Janeiro, Campus, 1997; Freitas, Marcos C. (org.): Historiografia brasileira em perspectiva, São Paulo, Contexto, 1998; MORAES, José Geraldo Vinci de \& REGO, José Marcio, Conversas com Historiadores Brasileiros, São Paulo, Editora 34, 2002; e, ainda, de SCHWARTZ, Stuart B.: «Depois da dependência: caminhos novos da historiografia brasileira» in Da América Portuguesa ao Brasil. Estudos Históricos, Lisboa, Difel, 2003, pp. 273-304.

2 ALDEN, Dauril: Royal Government in Colonial Brazil, Berkeley, University of California Press, 1968.

3 De Charles BOXer consulte-se a valiosa reedição da sua Opera Minora, Lisboa, Fundação Oriente, 2002-, dirigida por Diogo Ramada Curto.

4 RUSSELL-WOOD, A. J. R. «United States scholarly contributions to the historiography of Colonial Brazil», The Hispanic American Historical Review, 65 (4) pp. 683-723. JoHNsON, Harold \& SILVA, Maria Beatriz Nizza da (orgs.): O império luso-brasileiro, 1500-1620, Lisboa, Estampa, 1992 (Nova História da Expansão Portuguesa, vol. 6); Silva, Maria Beatriz Nizza da (org.): Sexualidade, família e religião na colonização do Brasil, Lisboa, Livros Horizontes, 2001.

5 FerLINI, Vera Amaral: Terra, Trabalho e Poder. $O$ mundo dos engenbos no Nordeste colonial, $2^{\text {a }}$ edição, Bauru, Edusc, 2003; veja-se também, de FerLINI, V.: A civilização do açúcar, séculos XVI a XVIII, São Paulo, Brasiliense, 1984.

6 SCHWARTZ, Stuart B.: Sovereignty and Society in Colonial Brazil. The High Court of Babia and its Judges 1609-1751, Berkeley-Los Angeles-Londres, UCP, 1973.

7 Russell_WOOD, A. J. R.: Fidalgos and Philanthropists. The Santa Casa da Misericórdia of Babia, 1550-1755, Londres, MacMillan, 1968. 
mos, igualmente, um decisivo contributo para o alargamento do leque de personagens estudado pelos historiadores do Brasil colonial. $\mathrm{Na}$ verdade, ao lado dos membros da elite colonial luso-brasileira, Schwartz fez surgir um grupo bastante diversificado de homens livres da sociedade colonial, grupo esse composto por pequenos proprietários de terras, por artesãos e por todos aqueles a quem a historiografia vinha concedendo um papel menos visível no antigo sistema colonial ${ }^{8}$.

$\mathrm{O}$ alargamento do leque dos actores da sociedade colonial envolveu, também, os Africanos e os Indígenas. Quanto aos primeiros, graças ao labor de Emília Viotti da Costa, de Kátia M. de Queirós Mattoso, de Alberto da Costa e Silva, de Stuart Schwartz ou de João José Reis, conhecemos hoje bastante melhor o seu contributo para a formação do Brasil colonial'. À linha de estudos sobre a escravidão devemos, sobretudo, o fim do predomínio do homem branco como único sujeito da sociedade colonial, e o reconhecimento do papel activo desempenhado pelos africanos ${ }^{10}$. Ao concentrarem a sua atenção no mundo dos negros, escravos ou livres, tais estudos trouxeram à luz um universo diversificado, dinâmico e extremamente vasto ${ }^{11}$.

Quanto aos Indígenas, os estudos de Manuela Carneiro da Cunha ou de John Manuel Monteiro também lhes devolveram um estatuto de protagonista activo do processo histórico brasileiro. Como apontou recentemente S. Schwartz, urge restituir às sociedades indígenas toda a sua dimensão sóciohistórica, e ter em conta que tais populações foram, também elas, produtoras da sua própria história, tendo sido muito mais do que simples vítimas passivas da colonização. Tal não significa negar a violência da conquista, o arbitrário da colonização ou o carácter assimétrico das relações entre europeus e indígenas. Pelo contrário, trata-se, sobretudo, de procurar captar as vozes indígenas mediante um apurado trabalho crítico sobre fontes, escritas e orais, na certeza, porém, de que tomar em conta essas fontes não equivale a considerá-las neutrais, não condicionadas por um determinado ponto de vista ou, porventura, mais autênticas do que as europeias ${ }^{12}$. Por outro lado, importa ter em conta

${ }^{8}$ SCHWARTZ, Stuart: Slaves, Peasants and rebels. Reconsidering Brazilian slavery, Urbana \& Chicago, August Meir \& John H. Bracey, 1992.

9 Cfr. maxime SCHWARTZ, Stuart: Sugar Plantations in the formation of Brazilian Society. Babia, 1550-1835, Cambridge, Cambridge University Press, 1985. Sobre a componente africana é imprescindível a consulta da obra de Alberto da Costa e SilvA, em especial $A$ Enxada e a Lança. A África antes dos Portugueses, São Paulo, Edusp, 1992; e, também de SILvA, A. da Costa e: A Manilha e o Libambo. A África e a escravidão de 1500 a 1700, Rio de Janeiro, Nova Fronteira / Fundação Biblioteca Nacional, 2002.

${ }_{10}$ RuSSELL-WOOD, A. J. R.: The Black Man in Slavery and Freedom in Colonial Brazil, Londres, Macmillan's, 1982.

1 MAGALHÃES, Joaquim Romero: «Os escravos e os emigrantes» in MATTOSO, José (coord.): História de Portugal, vol. 3, Joaquim Romero de Magalhães (dir.), No alvorecer da modernidade, Lisboa, 1993; veja-se, também, de SCHWARTZ, Stuart: «Os escravos: "remédio de todas as outras cousas"» in Bethencourt, F. \& Chauduri, K. (dirs.): História da Expansão Portuguesa, Lisboa, Círculo de Leitores, 1998, vol. II, pp. 232-247.

12 SCHWARTZ, Stuart \& SAlOMON, Frank: «"Un Américain (imaginaire) à Paris". Réponse à Carmen Bernand», Annales HSS, (mars-avril 2003) n 2, pp. 499-512. Sobre esta temática consulte- 
que a renovação historiográfica que temos vindo a descrever envolveu, também, algumas temáticas que, durante muito tempo, tiveram pouca continuidade e que só recentemente foram retomadas. Um caso ilustrativo do que acabámos de afirmar é o estudo dos grupos de comerciantes e as ligações que estabeleceram entre a Europa e a América do Sul, de que um dos melhores exemplos é o trabalho - inédito - de David Grant Smith ${ }^{13}$. Merecem igualmente referência as investigações sobre a Inquisição, sobre os Cristãos-novos e sobre os Judeus em terras sul-americanas, devedoras, sobretudo, do labor de José Gonçalves Salvador e de Anita Novinsky, mas também das recentes pesquisas de Nathan Wachtel ${ }^{14}$ e de Bruno Feitler ${ }^{15}$. Outra área de trabalho que actualmente suscita uma atenção crescente é a missionação, em especial o estudo das missões da Companhia de Jesus, um terreno onde Serafim Leite, nos anos de 1950 e 1960, desempenhou um papel de primeira importância. Recentemente surgiram vários novas pesquisas sobre as missões no Brasil durante o período dos Habsburgo, pesquisas essas que aprofundaram as propostas enunciadas por gerações anteriores de estudiosos - pensamos nos trabalhos de Dauril Alden ${ }^{16}$, de Charlotte de Castelnau ${ }^{17}$, de Carlos Zerón ${ }^{18}$ ou de Andréa Daher ${ }^{19}$.

Ao falarmos desta multifacetada renovação historiográfica não devemos olvidar os contributos que privilegiaram a dimensão cultural. Desde meados da década de 1980 que se registou a entrada em cena, na historiografia Brasileira, da «História das Mentalidades», e desse facto resultou a introdução de toda uma série de novos temas, problemáticas e métodos. Assim, questões como a magia, a feitiçaria, os hábitos sexuais, a vida familiar, a vida privada, etc., passaram a ser as temáticas mais exploradas por uma importante geração de histo-

se, de Almeida, Maria Regina Celestino de:, Metamorfoses Indígenas. Identidade e cultura nas aldeias coloniais do Rio de Janeiro. Rio de Janeiro, Arquivo Nacional, 2003.

13 SMITH, David Grant: The Mercantile Class of Portugal and Brazil in the Seventeenth Century. A Socioeconomic Study of the Merchants of Lisbon and Babia, Tese de Doutoramento, Austin, The University of Texas, 1975 .

14 WATCHEL, Nathan: La foi du souvenir. Labyrinthes marranes, Paris, Le Seuil, 2001.

is FEITLER, Bruno: Inquisition, juifs et nouveaux-chrétiens au Brésil; Lovaina, Leuven University Press, 2003. Para um recente estado da questão sobre esta área de estudos, veja-se, de VAINFAS, Renaldo: «A problemática das mentalidades e a Inquisição no Brasil Colonial», Estudos Históricos, Rio de Janeiro, 1988, pp. 161-173; ver, ainda, de Ana Margarida Pereira, A Inquisiçāo no Brasil. Aspectos da sua actuação nas Capitanias do Sul (de meados do séc. XVI ao início do século XVIII), Coimbra, Fauldade de Letras da Universidade de Coimbra, 2001.

16 ALDEN, Dauril: The Making of an Enterprise. The Society of Jesus in Portugal, its Empire and beyond, 1540-1750, Stanford, Stanford University Press, 1995.

17 CAStelnau, Charlotte de:, Les ouvriers d'une vigne stérile. Les jésuites et la conversion des Indiens au Brésil 1580-1620, Paris-Lisboa, Centre Culturel Calouste Gulbenkian-CNCDP, 2000.

18 Zeron, Carlos Alberto: La Compagnie de Jésus et l'institution de l'esclavage au Brésil. Les justifications d'ordre bistorique, théologique et juridique et leur intégration par une mémoire bistorique, Tese defendida na École des Hautes Études en Sciences Sociales, Paris, 1998.

19 DAHER, Andréa: Les singularités de la France équinoxiale. Histoire de la mission des pères capucins au Brésil (1612-1615), Paris, Honoré Champion, 2002.

Hispania, LXIV/1, núm. 216 (2004) 117-156 
riadores, entre os quais se destacam, pela qualidade da sua vasta obra, Laura de Mello e Souza ${ }^{20}$ e Ronaldo Vainfas ${ }^{21}$. Sem perderem de vista o contributo de Fernando Novais, estes e outros estudiosos exploraram novos campos de estudo, detectando muitas zonas onde o poder régio ou as autoridades religiosas eram incapazes de chegar, assim como formas diversificadas de resistência às imposições da Igreja e da Coroa.

Mas os avanços historiográficos registados nos últimos anos são também devedores de linhas de pesquisa desenvolvidas fora do mundo universitário. É esse o caso da fundamental obra de Evaldo Cabral de Mello, um historiador que, na senda dos estudos de José Antônio Gonsalves de Mello, cultivou, de um modo superior, uma história de enfoque Pernambucano. Distante das chamadas «macro-explicações» ou "macro-interpretações» do Brasil ${ }^{22}$, Evaldo Cabral de Mello interessou-se pelos anos em que o Brasil esteve sob a tutela dos Habsburgo, mas também pelo período final de Seiscentos, produzindo uma história política sempre solidamente apoiada num profundo conhecimento do contexto social e cultural daquela época. Revelando um invejável domínio dos mais diversos corpora documentais, Cabral de Mello tem-nos brindado com uma série de magistrais retratos do exercício do poder no chamado «Nordeste açucareiro" ${ }^{23}$. Um outro excelente exemplo dessa síntese entre renovação e continuidade é o contributo de Caio C. Boschi, materializado nos seus excelentes trabalhos sobre as irmandades leigas da região de Minas ${ }^{24}$, e ainda na eficaz coordenação de grandes projectos de identificação e de inventariação de massas documentais relevantes para a história do Brasil colonial.

${ }^{20}$ SouZA, Laura de Mello e: $O$ diabo e a terra de Santa Cruz. Feitiçaria e Religiosidade Popular no Brasil Colonial, São Paulo, Companhia das Letras, 1986; SoUZA, Laura de Mello e: Inferno Atlântico, São Paulo, Companhia das Letras, 1993; SOUZA, Laura de Mello e: (org.), Cotidiano e vida privada na América portuguesa, vol. I da História da Vida Privada do Brasil, coleç̧ão dirigida por NovaIs, Fernando A., São Paulo, Companhia das Letras, 1997; SILvA, Maria Beatriz Nizza da: A Cultura Portuguesa na Terra de Santa Cruz, Lisboa, Editorial Estampa, 1995.

21 VAINFAS, Ronaldo: Trópico dos Pecados. Moral, Sexualidade e Inquisiz̧ão no Brasil, Rio de Janeiro, Editora Campus, 1989; VAINFAS, R.: A beresia dos índios. Catolicismo e rebeldia no Brasil colonial, São Paulo, Companhia das Letras, 1995; VAINFAS, R. (org.): Dicionário do Brasil Colonial (15001808), Rio de Janeiro, Objetiva, 2000.

${ }_{22}$ Cfr. REIS, José Carlos: As Identidades do Brasil. De Varnhagen a FHC, Rio de Janeiro, Fundação Getúlio Vargas, $4^{\mathrm{a}}$ edição, 2001.

${ }_{23}$ MeLlo, Evaldo Cabral de: Olinda Restaurada. Guerra e açúcar no Nordeste, 1630-1654 [1975], Rio de Janeiro, Topbooks 1998; Rubro Veio. O Imaginário da Restauração Pernambucana [1986], Rio de Janeiro, Topbooks, 1997; MELLO, Evaldo Cabral de: O Norte Agrário e o Império (1871-1889) [1984], Rio de Janeiro, Topbooks, 1999; MELLO, Evaldo Cabral de:, A ferida de Narciso: ensaio de bistória regional, São Paulo, Editora SENAC, 2001; O Negócio do Brasil. Portugal, os Países Baixos e o Nordeste (1641-1669), Lisboa, CNCDP, 2001; Um imenso Portugal. História e Historiografia, São Paulo, Editora 34, 2002.

${ }^{24}$ BOSCHI, Caio César: Os Leigos e o Poder. Irmandades leigas e política colonizadora em Minas Gerais, São Paulo, Ática, 1986. 
Enquanto decorriam estes desenvolvimentos historiográficos no Brasil, a historiografia dedicada ao Portugal da época moderna atravessava também um período de apreciável transformação. De forma muito esquemática, diríamos que tal transformação assentou em três principais eixos: a prioridade concedida ao estudo das relações de poder, nas suas múltiplas configurações; uma maior abertura aos contributos das outras ciências sociais, através do reforço da ligação ao contexto e suas específicas características; a adopção de um entendimento mais aprofundado dos circuitos de produção, de difusão e de recepção das decisões políticas.

Esta renovação dos estudos sobre a dinâmica política da época moderna envolveu, antes de mais, o abandono do estudo «tradicionalista» e teleológico do itinerário histórico dos sistemas normativos. Tal implicou a adopção de um entendimento alargado do campo normativo, bem como a prática interpretativa mais sensível à comunicação entre as várias esferas de normatividade. Implicou, também, o esforço por alcançar uma compreensão abrangente do campo político, assim como a recusa de leituras lineares, modernizadoras e aperfeiçoadoras dos sistemas político-institucionais. Notou-se, também, uma preocupação renovada pela reconstituição da semântica das categorias e dos modelos vigentes no passado, por exemplo através do estudo da acepção coetânea de palavras como «império», «monarquia», "governo» ou "administração». Apesar de, no início, incidirem apenas no cenário europeu, com o tempo estas mudanças também se fizeram sentir nos estudos sobre o empreendimento imperial português, tanto no Oriente como no Atlântico.

Um outro importante contributo para o conhecimento da América do Sul sob os Habsburgo e os primeiros Bragança proveio da plurifacetada linha de pesquisas dedicada à Monarquia Hispânica. Como é bem sabido, nas últimas três décadas o estudo do conglomerado de territórios encabeçado pelos Habsburgo espanhóis foi profundamente renovado pelas investigações de muitos historiadores oriundos de Espanha, mas também do Reino Unido, de França, de Itália e dos Estados Unidos. John H. Elliott, Antonio Dominguez Ortiz, Bernard Vincent, Pablo Fernández Albaladejo, J. I. Fortea Pérez, Geoffrey Parker, Henry Kamen, I. A. A. Thompson, Jonathan Israel, Cesare Mozzarelli, Bartolomé Yun, entre muitos outros, contam-se entre os responsáveis por essa renovação. Portugal, como parte do agregado de reinos e de territórios que foi a Monarquia Hispânica, acabou por beneficiar desta revitalização, sobretudo graças aos contributos de António M. Hespanha ${ }^{25}$, de Fernando Bouza Alvarez ${ }^{26}$,

25 De Hespanha, António Manuel, veja-se, maxime, As Vésperas do Leviathan. Instituições e Poder Político - Portugal, século XVII, [1986], Coimbra, Almedina, 1994; HeSPANHA, António Manuel (dir.): História de Portugal, MATTOso, José (dir.), vol. IV, O Antigo Regime (1620-1807), Lisboa, Círculo de Leitores, 1993.

26 BOUZa Álvarez, Fernando: Portugal en la Monarquía Hispánica (1580-1640). Felipe II, la cortes de Tomar y la genesis del Portugal Católico, Madrid, Universidad Complutense, 1987.

Hispania, LXIV/1, núm. 216 (2004) 117-156 
de Santiago Luxán Meléndez ${ }^{27}$ e, mais recentemente, de Jean-Frédéric Schaub ${ }^{28}$ e de Rafael Valladares ${ }^{29}$.

Incidindo ostensivamente sobre a política, esta historiografia estudou, de um modo exaustivo, os órgãos de governo, a sua orgânica, o seu oficialato, a sua cultura funcional e a sua actuação em diversas conjunturas; estudou, também, as diversas formas de administração (conselhos palatinos, juntas, secretários de estado); os órgãos de administração territorial; as diversas configurações do serviço à Coroa (oficialato tradicional e modelo comissarial; juízes ordinários e comissários; magistratura e ethos aristocrático). Além das áreas temáticas que acabaram de ser referidas, estudou-se a valência política da corte régia, a etiqueta e o dispositivo cerimonial promovido pela monarquia. Foram analisadas as relações entre centro e periferia e suas implicações políticas, estudando-se também, de um modo aprofundado, a problemática da monarquia compósita e as questões de ordem constitucional a ela inerentes. Por último, reconstituiuse, com toda a minúcia, os processos de produção, de difusão e de recepção das decisões governativas, a fim de captar toda a complexidade de tais processos.

Muitos desses trabalhos proporcionaram descrições detalhadas das estruturas político-administrativas da Monarquia Hispânica, o que fez com que o Brasil, como parte dos domínios do Habsburgo, também tivesse sido alvo de alguma atenção. Privilegiando a dimensão político-institucional do Brasil dos Habsburgo e dos primeiros Bragança, esta linha historiográfica tem procurado descrever a orgânica do governo e da administração, mas também a sua cultura organizativa, os seus efectivos e, ainda, as suas complexas articulações com o meio social e económico em que se inseriam as suas práticas administrativas. Além disso, é uma linha de estudos que, para além da caracterização das instituições e da sua lógica de funcionamento, procura igualmente compreender o modo como os diversos grupos sociais que gravitavam em torno dessas instituições tiravam partido dos recursos por elas encerrados.

Muito embora algumas das mais importantes instituições do Brasil dos Habsburgo continuem à espera de um estudo aprofundado, para Portugal exis-

${ }^{27}$ LuXAN MelËNDeZ, Santiago de: La revolución de 1640 en Portugal, sus fundamentos sociales $y$ sus caracteres nacionales. El Consejo de Portugal: 1580-1640, Madrid, Universidad Complutense, 1988.

28 SCHAUB, Jean-Frédéric : Le Portugal au temps du comte-duc d'Olivares, 1621-1640. Le conflit de juridiction comme exercice de la politique, Madrid, Casa de Velazquez, 2001; idem, Portugal na Monarquia Hispânica (1580-1640), Lisboa, Livros Horizonte, 2001.

29 VALLADARES, Rafael: «El Brasil y las Indias españolas durante la sublevación de Portugal (1640-1668)», Cuadernos de Historia Moderna, 14 (1993) pp. 151-172; VALLADARES, Rafael: Felipe IV y la Restauración de Portugal, Málaga, Algazara, 1994; VAlladares, Rafael: La Rebelión de Portugal, 1640-1680. Guerra, conflicto y poderes en la monarquía bispánica, Valhadolid, Junta de Castilla y León, 1998. Veja-se, também, de STELLA, Roseli Santaella: $O$ domínio espanbol no Brasil durante a Monarquia dos Felipes, São Paulo, Unibrero, 2000; SANTOS, Ricardo Evaristo dos: El Brasil Filipino. 60 anos de presencia española en Brasil (1580-1640), Madrid, MAPFRE, 1993; SERRANO MANGAS, Fernando: La encrucijada portuguesa. Esplendor y quiebra de la unión ibérica en las Indias de Castilla (1600-1668), Badajoz, Diputación de Badajoz, 1994. 
te já uma série de monografias dedicadas ao dispositivo administrativo: António M. Hespanha efectuou uma análise sistemática do sistema políticoadministrativo português da época moderna; Joaquim Romero Magalhães explorou várias facetas da articulação entre o poder local e o poder central durante esse mesmo período; Nuno Gonçalo Monteiro estudou a ligação entre o universo da aristocracia e o serviço à Coroa, para além de ter produzido alguns dos mais importantes trabalhos sobre os municípios; José Subtil analisou, com detalhe, a actividade do tribunal do Desembargo do Paço no período Setecentista; Francisco Bethencourt retratou as diversas facetas do tribunal da lnquisição numa perspectiva comparada (Portugal, Espanha e Itália); Jean-Frédéric Schaub estudou o governo e a administração de Portugal sob D. Filipe III, desvendando algumas facetas até hoje pouco conhecidas da ruptura entre Portugal e a Monarquia Hispânica; Mafalda Soares da Cunha caracterizou exaustivamente a casa de Bragança e a sua relevância política na primeira metade de Seiscentos; Diogo Ramada Curto incidiu sobre o discurso político no Portugal de Quinhentos e de Seiscentos, tendo também produzido importantes trabalhos sobre o cerimonial da monarquia e sua relevância política; Maria Paula Lourenço estudou, com grande detalhe, a Casa do Infantado e a Casa das Rainhas; Maria Fernanda Olival realizou uma análise exaustiva da Ordens Militares e do papel por elas desempenhado no reforço do poder da Coroa durante a época moderna. Na última década o campo de estudos sobre a religião católica e o seu lugar no sistema político foi também enriquecido com trabalhos relevantes, com destaque para o já citado estudo de Francisco Bethencourt sobre a Inquisição, os estudos de José Pedro Paiva sobre os prelados e a organização diocesana, as pesquisas de Isabel dos Guimarães Sá acerca das Misericórdias, e a recente publicação da História Religiosa de Portugal, cujo volume dedicado à época moderna - dirigido por João Francisco Marques e António Camões Gouveia ${ }^{30}$ - contém numerosas páginas consagradas à acção da Igreja Católica na América do Sul.

\section{LACUNAS E NOVAS CONEXÓES}

A despeito de todos os desenvolvimentos que acabámos de delinear, não há dúvida de que a historiografia dedicada à história Quinhentista e Seiscentista do Brasil continua a apresentar algumas lacunas. Antes de mais, e como sugerimos atrás, está ainda por fazer a fixação da factologia básica da dinâmica política, faltando, também, monografias de instituições fundamentais. Essa carência é especialmente sentida no período inicial da colonização, para o qual os estudos existentes estão longe de ser numerosos ${ }^{3 i}$.

${ }^{30}$ MARQues, João Francisco \& Gouveia, António Camões (coords.): Humanismos e Reformas, vol. 2 da História Religiosa de Portugal, direcção de Carlos Moreira de AzEvedo, Lisboa, Círculo de Leitores, 2001.

31 Cfr. Couto, Jorge: A construção do Brasil. Ameríndios, portugueses e africanos, do início do povoamento a finais de Quinhentos, Lisboa, Edições Cosmos, 1995; MAGALHÃES, Joaquim Romero: «A 
Por outro lado, a dinâmica económica e comercial, depois de um longo tempo em que foi quase negligenciada, só agora começa a ser melhor conhecida graças às recentes e valiosas contribuições de Jonathan Israe ${ }^{32}$, de Jorge Pedreira ${ }^{33}$, de João Fragoso ${ }^{34}$, de Manolo Florentino ${ }^{35}$ ou de Leonor Freire Costa $^{36}$. Note-se que no contexto historiográfico norte-americano a dimensão sócio-económica sempre esteve muito mais presente, designadamente nos trabalhos que David Grant Smith, Stuart Schwartz ou A. J. R. Russell-Wood dedicaram à componente mercantil da expansão lusitana.

Além disso, é inegável que alguma historiografia portuguesa parece ainda demasiado centrada no reino, esquecendo que na época moderna existia uma forte articulação entre os domínios europeus da Coroa lusitana e os seus territórios americanos, africanos e asiáticos. Acresce que em certas áreas académicas foram criados compartimentos temáticos pouco pertinentes para a completa compreensão dos fluxos de trocas ou dos elos de conexão entre as várias regiões do conjunto imperial. Pouco pertinentes porque introduziram uma separação entre a dinâmica vivida no reino e aquela que foi a evolução nas possessões territoriais da Coroa portuguesa no Atlântico Sul. Para aqueles que viveram no período compreendido nos séculos XVI e XVII não fazia sentido pensar Portugal ou a Monarquia Hispânica separada das suas possessões ultramarinas, razão pela qual se torna imprescindível que a historiografia tenha em conta esse aspecto.

O problema que acabou de ser referido revela que subsiste uma certa dificuldade em articular a história do reino com a dinâmica registada nas possessões ultramarinas, notando-se, também, problemas na abordagem das várias parcelas do império de um modo sincrónico. Não menos gravosas são as lacunas que decorrem do facto de alguma historiografia investir apenas no estudo das primeiras décadas do empreendimento imperial português, encarando tal período como o momento mais decisivo e mais positivo da expansão lusitana. Tal concentração de estudos na primeira metade do século XVI faz com que

construção do espaço brasileiro» in BETHENCOURT, F. e CHAUDUR, K. (dirs.): História da Expansão Portuguesa..., cit., vol. II, 1998, pp. 28 segs.

${ }^{32}$ Cfr. maxime ISRAEL, Jonathan I.: Conflicts of Empires. Spain, the Low Countries and the struggle for world supremacy, 1585-1713, Londres, Hambledom Press, 1997.

33 PeDreira, Jorge : Os homens de negócio da praça de Lisboa de Pombal ao vintismo (1755-1822) diferenciação, reprodução e identificaçāo de um grupo social, Lisboa, Dissertação de Doutoramento, Universidade Nova de Lisboa, 1995 (policopiado).

34 FRAGOSO, João: consulte-se Homens de grossa aventura. Acumulação e bierarquia na praça mercantil do Rio de Janeiro (1790-1830), Rio de Janeiro, Arquivo Nacional, 1992; e A economia colonial brasileira (séculos XVI-XIX), $2^{\mathrm{a}}$ edição, São Paulo, Atual, 2000; e $O$ arcaísmo como projeto. Mercado atlântico, sociedade agrária e elite mercantil em uma economia colonial tardia. Rio de Janeiro, c.1790-c.1840, Rio de Janeiro, Civilização Brasileira, 2001.

35 FloRentino, Manolo: Em costas negras. Uma historia do trafico atlântico de escravos entre a África e o Rio de Janeiro, séculos XVIII e XIX, Rio de Janeiro, Arquivo Nacional, 1995.

${ }^{36}$ CosTA, Leonor Freire: Império e grupos mercantis. Entre o Oriente e o Atlântico (século XVII), Lisboa, Livros Horizonte, 2002. 
ainda hoje prevaleça um grande desconhecimento sobre o devir do império a partir do último quartel do século XVI, período muitas vezes (impropriamente?) qualificado como um tempo de «declínio» ou de «decadência». Além disso, entre muitos estudiosos portugueses nota-se uma persistente tendência para privilegiar a parte oriental dos domínios imperiais da Coroa lusitana, deixando no esquecimento o mundo Atlântico ${ }^{37}$.

Outro aspecto a registar: a historiografia portuguesa muitas vezes eufemizou a componente destruidora e politicamente dominadora da presença lusa no Atlântico do Sul, valorizando, em contrapartida, a parte Oriental do Império e as façanhas militares que aí tiveram lugar. A este facto há que juntar o apego a interpretações do empreendimento imperial com um cariz nacionalista ${ }^{38}$, frequentemente associadas ao que poderíamos classificar como a sobrevivência de formas mais ou menos subtis da ideologia «luso-tropical», bem visível na insistência em temas como a ideologia de cruzada, ou na deliberada omissão da dimensão destruidora do domínio imperial. Apesar do esforço historiográfico desenvolvido por uma série de estudiosos brasileiros - em particular pela chamada «Escola Paulista» - para desmistificar a suposta cordialidade racial lusobrasileira, em Portugal os ecos luso-tropicalistas ainda são escutados em alguns estudos, continuando-se a defender, aqui e ali, a natural tolerância portuguesa face às demais culturas, ou a inata cordialidade dos lusos e a sua predisposição para a multi-etnicidade e para o multiculturalismo. A idealização das relações estabelecidas entre os portugueses-colonizadores e os povos colonizados é outra expressão desse renitente luso-tropicalismo, o mesmo se podendo dizer da expressão «Encontro de Culturas», criada para representar a acção evangelizadora como um processo pacífico, benéfico e vantajoso para os povos não-europeus ${ }^{39}$.

Além da que acabou de ser referida, uma outra flagrante lacuna relacionase com a persistente omissão de um tema incómodo: o tráfico de escravos. É importante ter em conta que são poucos os historiadores portugueses que se dedicam ao trato escravista, à escravidão e à história dos povos africanos deslocados para a América. Por ser uma questão pouco amável, a escravatura tem sido uma temática evitada por muitos historiadores, tanto lusos como brasileiros, e as pesquisas de Didier Lahon, de Valentim Alexandre, de João Pedro Marques, de Maria do Rosário Pimentel, de Isabel Castro Henriques ou de Maria da Graça Ventura constituem, provavelmente, as poucas excepções ao que

\footnotetext{
37 Acerca deste tema consulte-se, de XAVIER, Ângela Barreto: «Tendências na historiografia da expansão portuguesa: reflexões sobre os destinos da história social», Penélope. Revista de História e Ciências Sociais, 22 (2000) pp. 141-179.

38 Para uma boa problematização sobre esta temática, cfr. CATROGA, Fernando: «Ritualizações da História» in TORGAL, Luís Reis et al., História da História em Portugal, sécs. XIX-XX, Lisboa, Círculo de Leitores, 1996, pp. 547-671.

39 Veja-se, por exemplo, Encontro de culturas oito séculos de missionação portuguesa, catálogo de exposição organizada pela Conferência Episcopal Portuguesa, Lisboa, CEP, 1996.

Hispania, LXIV/1, núm. 216 (2004) 117-156
} 
acabámos de afirmar ${ }^{40}$. No que respeita especificamente à história do conjunto da América meridional, refira-se, também, a falta de trabalhos que relacionem o contexto do Brasil colonial com a situação vivida nas várias regiões que integravam a América Espanhola ${ }^{41}$. A divisão académica das disciplinas com base em critérios nacionais ainda mais acentuou esta ausência de estudos relacionais, pois definiu fronteiras temáticas que não se revelam pertinentes para o tipo de abordagem que será conveniente desenvolver para o caso dos impérios português e espanhol.

Apesar de várias destas lacunas subsistirem, actualmente pode dizer-se que a situação é já bem diversa, e para essa mutação contribuiu, antes de mais, a iniciativa de um número crescente de pesquisadores brasileiros que acorreram à Península Ibérica não só para estudar fontes arquivísticas, mas também para encetar um diálogo frutuoso com os seus congéneres ibéricos. Neste quadro foi importante a acção desenvolvida quer pela Cátedra «Jaime Cortesão» (da Faculdade de Filosofia, Letras e Ciências Humanas da Universidade de São Paulo) ${ }^{42}$, quer pela Comissão Nacional para as Comemorações dos Descobrimentos Portugueses (CNCDP), instituição que promoveu edições, apoiou reuniões científicas, projectos de investigação, viagens de investigadores dos dois lados

40 Pimentel, Maria do Rosário:, Viagem ao fundo das consciências. A escravatura na Época Moderna, Lisboa, Edições Colibri, 1995; VentuRA, Maria da Graça: Negreiros portugueses na rota das Índias de Castela, 1541-1556, Lisboa, Colibri - Instituto de Cultura Ibero-Atlântico, 1998; idem, Portugueses no descobrimento e conquista da Hispano-América. Viagens e expediçōes (1492-1557), Lisboa, Colibri, 2000; ARes Quejia, Berta e STElla, Alessandro (orgs.): Negros, Mulatos, Zambaigos. Derroteros africanos en los mundos ibéricos, Sevilha, CSIC, 2000; LAHON, Didier: O Negro no coração do Império. Uma memória a resgatar, séculos XV-XIX, Lisboa, Entreculturas, 1999; LAHON, Didier: Esclavage et confréries noires au Portugal durant l'Ancien Régime (1441-1830), tese defendida na École des Hautes Études en Sciences Sociales, Paris, 2001; STELlA, Alessandro: Histoires d'esclaves dans la Péninsule ibérique, Paris, École des Hautes Études en Sciences Sociales, 2000; FONSECA, Jorge: Escravos no sul de Portugal. Séculos XVI-XVII, Rota do Escravo ${ }^{\circ} 2$, Lisboa, Vulgata, 2002; HenRIQUES, Isabel Castro (coord.): Novas Relaçöes com África: que perspectivas?, Lisboa, Vulgata, 2003.

${ }^{41} \mathrm{Na}$ linha das propostas de RuSSELL-WOOD, A. J. R. (org.): Government and Governance of European Empires, 1450-1800, Brookfield, Ashgate, 2000; para a parte oriental dos impérios ibéricos dispomos já do estudo de VALLADARES, Rafael: Castilla y Portugal en Asia (1580-1680). Declive imperial y adaptación, Lovaina, Leuven University Press, 2001. Sobre o tema consulte-se, igualmente, BETHENCOURT, F.: «Competição entre Impérios Europeus» in BETHENCOURT, F. \& CHAUDHURI (dirs.): História da Expansão Portuguesa..., cit., 1998, vol. II, pp. 361-382; de GrUZINSKI, Serge: «A América Española vista a partir do Brasil portugués» in AA. VV., Portugal-Brasil. Memórias e Imaginário, Lisboa, GTMECDP, 2000, pp. 232-244; veja-se, também, de VENTURA, Maria da Graça: «A fluidez de fronteiras entre o Brasil e a América Española no período colonial» in PIMENTEL, Maria do Rosário: Portugal e Brasil no advento do Mundo Moderno, Lisboa, Edições Colibri, 2001, pp. 257-268.

${ }^{42}$ Consulte-se, de ARRUDA, José Jobson e TENGARRINHA, José Manuel (orgs.): Historiografia LusoBrasileira Contemporânea, Bauru, EDUSC, 1999; ARRUDA, José Jobson e FONSECA, Luís Adão da (orgs.): Brasil-Portugal. História, agenda para o milénio, Bauru, FAPESP, EDUSC, ICCTI, 2001; e, de TENGARRINHA, José Manuel (org.): História de Portugal, São Paulo, Instituto Camões/UNESP/EDUSC, 2000. 
do Atlântico e, ainda, a edição de importantes conjuntos documentais ${ }^{43}$. O legado da CNCDP é marcante, pois sempre soube romper, de forma subtil mas determinada, com a abordagem eurocêntrica que caracterizava a maioria dos estudos produzidos até tempos recentes. Além disso, essa instituição teve o mérito de conseguir dar a conhecer ao público português a pluralidade de pontos de vista sobre o seu passado imperial, rompendo com o tradicional predomínio do ponto de vista do colonizador ${ }^{44}$.

A publicação dos vários volumes da obra História da Expansão Portuguesa, dirigida por Francisco Bethencourt e Kirti Chaudhuri ${ }^{45}$, teve também um importante efeito de relançamento da História da Expansão em Portugal, introduzindo novos problemas, questionando outros, dando a conhecer historiografias estrangeiras sobre o império português e aproximando os investigadores lusos dos seus congéneres lusófonos - especialmente os brasileiros. Além disso, trata-se de uma obra que demonstra uma grande insistência em abordagens sincrónicas, procurando detectar interacções. (e conexões) entre as várias partes do império português.

Num plano mais geral, esta transformação do campo de estudos sobre a história brasileira do período dos Habsburgo e dos primeiros Bragança também beneficiou da vaga de investigações sobre o Colonialismo e o Pós-colonialismo ${ }^{46}$. A afirmação académica destas áreas de estudo levou um número crescente de estudiosos a interessar-se, de um modo "renovado", pelas experiências colonizadoras registadas a partir do século XVI. Num primeiro momento, talvez por estarem muito ligados aos meios universitários anglo-saxónicos, os estudos póscoloniais incidiram sobretudo no empreendimento colonial britânico no Oriente, em especial na Índia de finais de Setecentos e do século XIX. Contudo, com

${ }_{43}$ Como derradeiro exemplo da qualidade das edições da Comissão Nacional para as Comemorações dos Descobrimentos Portugueses veja-se, relativamente ao Brasil: Cartas para Álvaro de Sousa e Gaspar de Sousa, Lisboa, edição de João Paulo Salvado e Susana Münch Miranda, Lisboa, CNCDP, 2003; o Livro $1^{\circ}$ do Governo do Brasil, edição de João Paulo SALVADo e Susana Münch MIRANDA, Lisboa, CNCDP, 2003; e as Cartas do $1^{\circ}$ Conde da Torre, edição de João Paulo SAlvADO e Susana Münch MiRANDA, Lisboa, CNCDP, 2003.

${ }_{44}$ Cfr. Herschmann, Micael \& Pereira, Carlos Alberto Messeder: «E la Nave Va... As celebrações dos 500 Anos no Brasil. Afirmaçōes e Disputas no espaço Simbólico», Estudos Históricos, Rio de Janeiro, vol. 14, $\mathrm{n}^{\circ} 26$ (2000) pp. 203-215; e OliveirA, Lucia Lippi:, «Imaginário Histórico e Poder Cultural: as Comemorações do Descobrimento», Estudos Históricos, Rio de Janeiro, vol. 14, ${ }^{\circ}$ 26 (2000) pp. 183-202.

45 BethenCourt, F. e Chaudhuri, K. (dirs.): História da expansão portuguesa, vol. 1, 2 \& 3, Lisboa, Círculo de Leitores, 1998-1999; cfr. com MAURO, F. (coord.): O Império Luso-Brasileiro, 1620-1750, vol. VII da Nova História da Expansão Portuguesa, dirigida por SERRÃO, Joel e MARQUES, A. H. de Oliveira, Lisboa, Editorial Estampa, 1991.

46 Entre a vastíssima bibliografia recente, consulte-se, de ALMEIDA, Miguel Vale de: «O Atlântico Pardo. Antropologia, pós-colonialismo e o caso "lusófono"» in BASTOS, Cristiana, ALMEIDA, Miguel Vale de, \& FELDMAN-BIANCO, Bela (orgs.): Trânsitos coloniais: diálogos críticos luso-brasileiros, Lisboa, Imprensa de Ciências Sociais, 2002, pp. 23-38.

Hispania, LXIV/1, núm. 216 (2004) 117-156 
o tempo estes estudiosos foram-se dando conta de que existiam outras experiências coloniais europeias também merecedoras de atenção, e cronologicamente anteriores à Britânica: os impérios Ibéricos do período compreendido entre os séculos XVI e XVIII. Na sequência disso, o caso da Monarquia Hispânica e do seu império foi intensamente estudado - um fenómeno que coincidiu com as comemorações da viagem de Cristóvão Colombo, em 1992 -, e algum tempo mais tarde os domínios ultramarinos da Coroa portuguesa foram alvo da mesma atenção.

Neste quadro, uma das áreas que mais interesse tem suscitado é a temática das identidades ${ }^{47}$, da mestiçagem e das justaposições culturais ${ }^{48}$. Hoje sabemos que a mestiçagem, enquanto resultado da fragmentação das sociedades indígenas na América, correspondeu, nalguns casos, a uma estratégia de resistência, embora tenha sido um fenómeno que decorreu, também, da grande mobilidade que caracterizava aquelas sociedades ${ }^{49}$. Verificou-se que, em muitas ocasiões, era precisamente no terreno da mestiçagem que se dava o verdadeiro confronto entre a Ocidentalização e as formas culturais locais. Importa reter, no entanto, que o resultado deste processo nem sempre foi uma fusão entre as várias. comunidades, registando-se desenvolvimentos paralelos, uma coexistência que chegou a estender-se até aos nossos dias ${ }^{50}$. No que toca ao contexto brasileiro, para além dos trabalhos de João José Reis ${ }^{51}$, neste terreno é obrigatório men-

47 CURTo, Diogo Ramada , "Cultura escrita e práticas de identidade» in BETHENCOURT, F. \& Chaudhuri, K. (dirs.): História da Expansão Portuguesa..., cit., vol. II, 1998, pp. 458-531.

48 Veja-se, in genere, a obra de Serge Gruzinski; consulte-se igualmente LOUREIRO, Rui Manuel \& GRuZINSKI, S. (orgs.): Passar as Fronteiras. Actas do II Colóquio Internacional sobre Mediadores Culturais, séculos XV a XVIII, Lagos, Centro de Estudos Gil Eanes, 1999; vide também, de SCHWARTZ, Stuart (org.): Implicit Understandings. Observing, reporting, and reflecting on the encounters between Europeans and other Peoples in the Early Modern Era, Cambridge, Cambridge University Press, 1994; e, de Bastos, Cristiana, Almeida, Miguel Vale de \& Feldman-Bianco (orgs.): Trânsitos coloniais: diálogos críticos luso-brasileiros, Lisboa, Imprensa de Ciências Sociais, 2002.

49 Cfr. Greenblatt, Stephen: «The Go-Between» in Marvelous Possessions. The Wonder of the New World, Oxford, Clarendon Press, 1991, pp. 119 segs. Para o contexto imperial português, veja-se, de Russell-Wood, A. J. R. A World on the Move. The Portuguese in Africa, Asia, and America, 1415-1808, Carcanet Press, Manchester and St. Martin's Press, New York, 1992; RUSSELL-WODD, A. J. R.: «Fronteiras da Integração» in BETHENCOURT, F. \& CHAUDHURI, K. (dirs.): História da Expansão Portuguesa..., cit., vol. I, 1998, pp. 238 segs.; e, também de RUSSELL-WOOD, «População e Sociedade» in BethenCourt, F. e CHAUdhur, K. (dirs.): História da expansão portuguesa..., cit., 1998, vol. II, pp. 126 segs.; RoDrigues, José Damião: «Entre Duas Margens. A circulação Atlântica dos Açorianos nos

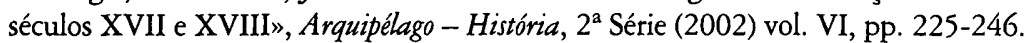

so ARes QueIJA, Berta \& GruZINSKI, Serge (orgs.): Entre dos mundos. Fronteras Culturales y Agentes Mediadores, Sevilha, Escuela de Estudios Hispano-Americanos, 1997. Almeida, Miguel Vale de: Um Mar Cor da terra. Raşa, Cultura e Política da Identidade, Oeiras, Celta, 2000.

s1 REIS, João José: Negociação e conflito. A resistência negra no Brasil escravista, com SILVA, Eduardo, São Paulo, Companhia das Letras, 1981; ReIS, João José \& GOMES, Flávio dos Santos (orgs.): Liberdade por um fio. História dos Quilombos no Brasil, São Paulo, Companhia das Letras, 1996. Sobre o 
cionar o labor de Sílvia Hunold Lara, autora de vários estudos sobre as populações africanas deportadas para o Brasil. Concedendo um especial destaque aos padrões identitários africanos e à sua transformação no decurso da passagem para a América, Sílvia Lara reconstituiu o complexo processo de redimensionamento das tradições africanas resultante do contacto com novos contextos demográficos e sociais ${ }^{52}$.

Em parte devido aos vários contributos que acabaram de ser assinalados, a renovação do campo de estudos sobre o Brasil de Quinhentos e de Seiscentos não tem cessado, e nos últimos dez anos foram formuladas diversas perspectivas inovadoras. Refira-se, desde já, que se nota um maior interesse por temas até hoje pouco estudados, caso do mundo da escravização de africanos e de indígenas. $\mathrm{Na}$ senda dos trabalhos de João José Reis, de Manuela Carneiro da Cunha ${ }^{53}$, de John Manuel Monteiro ${ }^{54}$ ou de Sílvia Hunold Lara ${ }^{55}$, os africanos e os indígenas - os "vencidos", os subalternos - parecem ter adquirido, por fim, o estatuto de sujeitos de primeiro plano da dinâmica histórica do período colonial.

Paralelamente, empreendeu-se o estudo da factologia básica de certos períodos fulcrais da história da América Portuguesa no período dos Habsburgo, na linha do que já começara a ser efectuado por Evaldo Cabral de Mello, por Caio Boschi ${ }^{56}$ ou por Joaquim Romero Magalhães ${ }^{57}$. Os exemplos mais recentes são os estudos de Luiz Felipe de Alencastro ${ }^{58}$, de Pedro Puntonis9, de Roseli Santaella Stella ${ }^{60}$, de Leonor Freire Costa ${ }^{61}$ ou de Guida Marques ${ }^{62}$.

tema da escravidão, veja-se, também, de SILVA, Maria Beatriz Nizza da (org.): Brasil: colonização e escravidão, Rio de Janeiro, Editora Nova Fronteira, 2000.

52 LARA, Sílvia Hunold: Campos de Violência - Escravos e Senbores na Capitania do Rio de Janeiro 1750 - 1808, Rio de Janeiro, Paz e Terra, 1988. Para além da identidade propriamente cultural, a problemática religiosa é outra das áreas mais exploradas neste campo de estudos da mestiçagem, sendo a esse respeito exemplar o estudo que Nathan Wachtel dedicou à complexa identidade religiosa dos judaizantes que viveram na América. Baseado em quarenta processos inquisitoriais conservados na Cidade do México, em Lima, em Lisboa e em Madrid, Wachtel privilegia temas como o sincretismo e a mestiçagem religiosa - cfr. WACHTEL, Nathan: La foi du souvenir. Labyrintbes marranes, Paris, Le Seuil, 2001; ver, ainda, de CALAINHO, Daniela, Metrópole das Mandingas. Religiosidade Negra e Inquisiçaõ Portuguesa no Antigo Regime, Niterói, Universidade Federal Fluminense, 2000.

53 Cunha, Manuela Carneiro da (dir.): História do Índios do Brasil, São Paulo, Companhia das Letras, 1992.

${ }^{44}$ MONTEIRo, John Manuel: Negros da terra. Índios e bandeirantes nas origens de São Paulo, São Paulo, Companhia das Letras, 1994.

5s LARA, Sílvia: «Linguagem, domínio senhorial e identidade étnica nas Minas Gerais de meados do século XVIII» in Bastos, Cristiana, Almeida, Miguel Vale de \& Feldman-Bianco, Bela (orgs.): Trânsitos coloniais: diálogos críticos luso-brasileiros, Lisboa, Imprensa de Ciências Sociais, 2002, pp. 205-226.

56. BosCHI, Caio: Os Leigos e o Poder...., cit., 1986.

57 MAGALHÃES, Joaquim Romero: «A construção do espaço brasileiro» in BETHENCOURT, F. e Chaudhuri, K. (dirs.): História da Expansão Portuguesa..., cit., vol. II, 1998, p. 28-64.

${ }_{58}$ Alencastro, Luiz Felipe de: $O$ Trato dos Viventes. Formação do Brasil no Atlântico sul, São Paulo, Companhia das Letras, 2001.

Hispania, LXIV/1, núm. 216 (2004) 117-156 
Nota-se também um maior investimento no estudo da dimensão cultural e literária do empreendimento colonizador ${ }^{63}$, com pesquisas que incidem em grandes vultos da literatura luso-brasileira, caso de António Vieira, mas também em outras figuras, como Gregório de Matos ${ }^{64}$. Este interesse pela dimensão literária tem também privilegiado as manifestações de Messianismo e de Sebastianismo em solo sul-americano durante o período dos Habsburgo (Jaqueline Hermann ${ }^{65}$, Thomas Cohen ${ }^{66}$, Ana Paula Megiani ${ }^{67}$ ), através do estudo dos valores e das categorias, assim como do modo como a experiência americana criou novas identidades e novos entendimentos do ser humano e da sua inserção na vida colectiva ${ }^{68}$. Analisada foi também a normatividade que era intrínseca a esse processo de interacção cultural - neste caso, veja-se, sobretudo, os excelentes trabalhos de Laura de Mello e Souza e de Ronaldo Vainfas ${ }^{69}$.

No essencial, dir-se-ia que se procedeu a uma inversão do enfoque, estudando-se agora não só o impacto das formas culturais europeias nos trópicos, mas também o modo como a experiência colonial afectou e modelou a Europa, em áreas tão diversas como a política, a economia, a guerra, o tecido social ou as artes visuais. No fundo, deixou-se de olhar exclusivamente para o lado do

59 PUNTONI, Pedro: A Mísera Sorte. A Escravidão Africana no Brasil Holandês e as Guerras do Tráfico no Atlântico Sul, 1621-1648, São Paulo, Hucitec, 1999; também de PUNTONI, P.: A Guerra dos Bárbaros. Povos indígenas e a colonizaşão do sertão. Nordeste do Brasil, 1650-1720, São Paulo, Edusup-Fapesp, 2000.

60 STELla: $O$ domínio espanbol no Brasil..., cit., 2000.

${ }^{61}$ Costa, Leonor Freire: $O$ transporte no Atlântico e a Companbia Geral do Comércio do Brasil (1580-1663), Lisboa, CNCDP, 2002.

62 MARQues, Guida: «O Estado do Brasil na União Ibérica: dinâmicas políticas no Brasil no tempo de Filipe II de Portugal», Penélope. Revista de História e Ciências Sociais, n 27 (2002) pp. 7-35.

63 Cfr. Almeida, Palmira: Dicionário de Autores no Brasil Colonial, Lisboa, Colibri, 2003.

64 PÉCORA, Alcir: Teatro do Sacramento. A unidade teológico-retórico-política dos sermões de António Vieira, São Paulo, Universidade, 1994; e, também de PÉCORA, A.: Máquina de gêneros, São Paulo, Edusp, 2001. HANSEN, João Adolfo: A sátira e o engenho. Gregório de Matos e a Babia do século XVII, São Paulo, Companhia das Letras, 1989.

65 Hemann, Jacqueline: No reino do desejado. A construcão do Sebastianismo em Portugal, séculos XVI e XVII, São Paulo, Companhia das Letras, 1998.

66 COHEN, Thomas: The fire of tongues. António Vieira and the missionary church in Brazil and Portugal, Stanford, Stanford University Press, 1998.

67 Megiani, Ana Paula: O Jovem Rei Encantado. Expectativas de Messianismo Régio em Portugal, sécs. XIII a XVI, São Paulo, Hucitec, 2003.

${ }^{68}$ Cfr. CURTo, Diogo Ramada: «A literatura e o império: entre o espírito cavaleiroso, as trocas da corte e o humanismo cívico" in BETHENCOURT, F. \& CHAUDHURI, K. (dirs.): História da Expansão Portuguesa, Lisboa, Círculo de Leitores, vol. II, 1998, pp. 434-454.

69 Veja-se in genere SouZA, Laura de Mello e (org.): História da Vida Privada do Brasil. Cotidiano e vida privada na América portuguesa, São Paulo, Companhia das Letras, 1997; SouZA, Laura de Mello e: Inferno atlântico. Demonologia e colonização. Séculos XVI-XVII, São Paulo, Companhia das Letras, 1993; de VAINFAS, Ronaldo (org.): Confissões da Babia, São Paulo, Companhia das Letras, 1997; MELlo, Evaldo Cabral de: "Como manipular a Inquisição» in E. Cabral de Mello, Um imenso Portugal. História e Historiografia, São Paulo, Editora 34, 2002, pp.127-146. 
colonizador, tomando-se agora como unidade de análise a mútua constituição do colonizador e do colonizado ${ }^{70}$. Nas palavras de Antonio Carlos de Souza Lima, "para se entender as (ex)metrópoles é preciso entender as suas (ex)colónias, as redes de interdependência e as tradições de conhecimento que as articula(ra)m, inclusive no plano das condutas, de padrões de interacção e formas estereotipadas de comunicação, dos símbolos e das ideias, reconhecendo o quanto os processos de formação do estado e de construção de nações na Europa devem, também, à experimentação nos mundos coloniais» ${ }^{71}$.

Finalmente, e de novo a política, regista-se uma atenção renovada pelos instrumentos político-administrativos implantados na América sob os Habsburgo e os primeiros Bragança, notando-se igualmente o interesse pelas diversas respostas que, a um nível local, foram dadas a essa imposição de mecanismos reguladores. A esse respeito, sabemos hoje que, em alguns casos, a resposta foi de rejeição, embora se saiba, também que em muitos outros a reaç̧ão foi de acomodação e de adaptação. Noutros contextos, ainda, a presença da Coroa chegou mesmo a ser solicitada como fonte de recursos para lidar com tensões locais, ou para mediar conflitos entre bandos que integravam o universo político sul-americano. Este é claramente um campo onde se poderá beneficiar muito dos conhecimentos adquiridos sobre a Monarquia Hispânica e sobre o lugar que Portugal ocupou nesse compósito agregado de reinos e de territórios ${ }^{72}$.

Por outro lado, o conhecimento mais apurado das condições de exercício do poder no quadro do Antigo Regime tornou possível uma avaliação mais consistente das práticas de dominação colonial, tanto dos Habsburgo como dos Bragança. Questionou-se, desde logo, a noção de que existia uma direcção firme e coordenada, por parte da Coroa, dos vários espaços imperiais. Como recordou recentemente António Hespanha ${ }^{73}$, uma das realidades com que tiveram de lidar aqueles que governaram o império português foi a inexistência de um estatuto jurídico unificado para todo o império. Os territórios extra-europeus que integravam os domínios da Coroa portuguesa caracterizavam-se por uma

\footnotetext{
70 Bastos, Cristiana, Almeida, Miguel Vale de \& Feldman-Bianco, Bela, «Introdução», Trânsitos coloniais: diálogos críticos luso-brasileiros, Lisboa, Imprensa de.Ciências Sociais, 2002, p. 12.

71 LIMA. Antonio Carlos de Souza: «Tradições de conhecimento na gestão colonial da desigualdade: reflexões a partir da administração indigenista no Brasil» in BASTOS, Cristiana, ALMEIDA, Miguel Vale de \& FELDMAN-BIANCO, Bela (orgs.): Trânsitos coloniais: diálogos críticos luso-brasileiros, Lisboa, Imprensa de Ciências Sociais, 2002, pp. 151-172. Acerca deste mesmo tema, consulte-se, de FilHO, Rubem Barboza: Tradição e Artifício. Iberismo e Barroco na Formaçāo Americana, Belo Horizonte, Editora UFMG, 2000.

${ }_{72}$ Sobre este tema é fundamental a consulta da obra de BOUZA ÁtVAREZ, Fernando: Portugal en la Monarquía Hispánica (1580-1640)..., cit., 1987, e também do livro de SCHAUB, Jean-Frédéric: Portugal na Monarquia Hispânica, Lisboa, Livros Horizonte, 2001.

73 HeSPANHA, António Manuel: «A constituição do Império português. Revisão de alguns enviesamentos correntes» in FRAGOSO, João, BiCALHO, Maria Fernanda e GoUVÊA, Maria de Fátima (orgs.): O Antigo Regime nos Trópicos. A dinâmica imperial portuguesa (séculos XVI-XVIII), Rio de Janeiro, Civilização Brasileira, 2001, pp. 163-188.
}

Hispania, LXIV/1, núm. 216 (2004) 117-156 
enorme heterogeneidade física e cultural ${ }^{74}$; por uma situação de extremo pluralismo jurídico; pela vigência de direitos indígenas em diversas partes do império; e pela interpenetração entre instâncias jurídicas e conjuntos normativos europeus. Todas estas realidades têm de ser levadas em conta na avaliação do exercício do poder no âmbito do império português.

Além disso, o conhecimento das condições concretas de exercício do poder no Antigo Regime tornou também possível reavaliar outras interpretações correntes do império português. É esse o caso da insistência numa imagem centralizada do Império, e da tese de que sempre existiu uma clara direcção estratégica, uma "ideia de império", gizada e sistematicamente aplicada desde Lisboa ou desde Madrid. Como notou uma vez mais António M. Hespanha, a imagem de um império marcadamente centralizado foi corroborada quer por estudiosos oriundos do país colonizador, quer por historiadores provenientes dos territórios colonizados pelos lusos. Do ponto de vista do antigo colonizador, a visão nacionalista do passado sempre apreciou a ideia de que o império possuía uma direç̧ão forte e coordenada, falando em «Plano das Índias», em «Escola de Sagres, em «Política de Sigilo», em «Ideia Imperial» ou em «Ideologia de Cruzada", para desse modo reforçar a convicção de que a nação portuguesa só se realiza através da conquista e da "submissão civilizadora" de outros povos. Do ponto de vista do país que fora colonizado, convinha sublinhar a centralização e a força do colonialismo, retratando-o como um dispositivo implacável e institucionalmente pesado. A. M. Hespanha ${ }^{75}$ assinalou que ambas as interpretações que acabámos de referir enfermam de um optimismo excessivo acerca das capacidades da Coroa portuguesa para exercer a sua soberania em territórios tão distantes. Hoje são já plenamente conhecidas as dificuldades sentidas pelos reis portugueses para dominar, com eficácia, os seus pequenos domínios europeus. Em face desses dados, estamos actualmente em condições para reavaliar, de um modo mais pertinente, o efectivo impacto da autoridade régia nos vastíssimos territórios ultramarinos.

É bem provável que toda esta renovação conduza a mudanças no vocabulário conceptual. Aliás, a revisão lexical está já em curso desde há alguns anos, em especial no estimulante universo historiográfico brasileiro, onde se tèm discutido, com intensidade, a pertinência teórica de conceitos como «Império», ou "Colónia», a dicotomia "Metrópole/Colónia» e, sobretudo, a expressão «Brasilcolónia», ultimamente substituída por expressões como «América Portuguesa», «espaços coloniais», "Conquistas», ou por referentes geográfico-administrativios como «Estado do Brasil», Pernambuco ou Maranhão. Problemáticàtên sido, também, a tarefa de encontrar uma palavra pertinente para classificar os actores do processo histórico luso-brasileiro: «Colonos»? «Brasileiros»? «Brasílicos»?

${ }^{4}$ MORAES, Antonio Carlos Robert: Bases da formaçãa territorial do Brasil. O território colonial brasileiro no "longo" século XVI, São Paulo, Hucitec, 2000.

75 HeSPANHA, António Manuel: «A constituição do Império português..., cit., 2001, pp. 163-188.

Hispania, LXIV/1, núm. 216 (2004) 117-156 
«Luso-brasileiros»? A resposta não se revela fácil, sobretudo porque hoje é cada vez mais adquirido que o senhorio colonial não era nem colonizado nem colonizador. Este aliciante debate conceptual é um bom exemplo do clima de renovação que se vive no mundo historiográfico, sobretudo do lado brasileiro.

\section{O BRASIL SOB OS HABSBURGO E OS PRIMEIROS BRAGANÇA}

É inegável que existe já um conjunto significativo de historiadores que soube tirar partido das múltiplas aquisições que acabaram de ser enumeradas, renovando profundamente o campo historiográfico luso-brasileiro. Para além das obras já referidas de Laura de Mello e Souza, de Ronaldo Vainfas e de Sílvia Hunold Lara, penso também em Luiz Felipe de Alencastro, em Maria Fernanda Bicalho, em Fátima Gouvêa, em Luciano Figueiredo, em Pedro Puntoni, em Júnia Furtado, em Tiago C. P. dos Reis Miranda ${ }^{76}$, em Ângela Domingues ${ }^{77}$, em lara Lis Carvalho Souza ${ }^{78}$, em Rodrigo Bentes Monteiro ${ }^{79}$, em Guida Marques ${ }^{80}$, para citar apenas os mais directamente ligados ao estudo do Brasil de Seiscentos.

O alcance desta renovação historiográfica é muito visível nos trabalhos de todos estes estudiosos. Vejamos, como exemplo, as propostas interpretativas formuladas por Luiz Felipe de Alencastro acerca do Atlântico Seiscentista ${ }^{81}$, ou seja, o espaço onde a influência das Coroas Ibéricas se fez sentir com mais intensidade. A fim de explicar o relacionamento entre Portugal, a Monarquia Hispânica e o Brasil, Alencastro rompeu com o esquema bipolar que pauta quase todos os estudos dedicados a esta temática, introduzindo uma abordagem muito mais plural e dinâmica. Assim, em vez de bipolar, o ponto de vista proposto por Alencastro é multipolar, e nela os principais "protagonistas» são os vários «espaços coloniais». Alencastro fala de uma América Portuguesa composta por economias regionais e por comunidades dispersas, insistindo no carácter fragmentado de um território onde cada uma das partes era portadora de uma identidade particular, de uma específica lógica de funcionamento e de interesses próprios. Entre essas várias «re-

76 Miranda, Tiago Costa Pinto dos Reis: A Inocência da Razão. António Freire de Andrade Encerrabodes (1699-1783), São Paulo, 1998 (Tese de Doutoramento em História Social apresentada no Departamento de História da Faculdade de Filosofia, Letras e Ciências Humanas da Universidade de São Paulo).

77 Domingues, Ângela: Quando os índios eram vassalos. Colonização e relações de poder no norte do Brasil na segunda metade do século XVIII, Lisboa, CNCDP, 1999.

78 SouZA, Iara Lis Carvalho: Pátria Coroada. O Brasil como Corpo Político Autônomo, 1780-1831, São Paulo, Unesp, 1998.

79 MONTEIRO, Rodrigo Bentes: $O$ Rei no Espelho. A Monarquia Portuguesa e a colonização da América, 1640-1720, São Paulo, Hucitec, 2002.

80 MARQueS, Guida: «O Estado do Brasil na União Ibérica..., cit., 2002, pp. 7-35.

81 Luiz Felipe de AlenCASTRO, O trato dos viventes..., cit., 2001. 
giões» avulta o eixo Rio de Janeiro-Buenos Aires-Angola, onde prevalecem, também, os interesses «Peruleiros» e de Potosís ${ }^{82}$; a região da Bahia, sobretudo conectada com a Costa da Mina; e, finalmente, o núcleo Grão Pará-Maranhão, mais directamente ligado às Caraíbas e a Lisboa do que as demais regiões sulamericanas. No fundo, Alencastro abandona o clássico esquema dual de um relacionamento metrópole-colónia, dedicando uma muito maior atenção à multiplicidade de interesses coexistentes, multiplicidade essa que, em última análise, extrapolava os limites estanques da bipolaridade. Envereda, assim, por um esquema alternativo, concentrando a sua atenção na existência de espaços e de mercados interdependentes, com hierarquias múltiplas e complexas.

Luiz Felipe de Alencastro sustenta que os interesses ligados ao tráfico de escravos foram o elemento determinante para o processo que apelida de «formação do Brasil» ${ }^{83}$. Falando de «ventos negreiros» e das condições físicas e materiais que favoreceram a génese de uma «mentalidade escravocrata», Alencastro retrata um sistema social onde os interesses dos fornecedores de escrávos africanos se revelaram mais fortes do que os do abastecimento de mão-de-obra indígena. $\mathrm{O}$ autor de $O$ Trato dos Viventes chamou a atenção, também, para $\mathrm{o}$ papel desempenhado pelos «Assentos» negreiros - o primeiro deles foi arrematado em Madrid em 1595 -, porque tais contratos terão alegadamente contribuído para consolidar, nas décadas que se seguiram, um grupo com fortíssimos interesses no tráfico (de que faziam parte os Sousa Coutinho, os Mendes de Vasconcelos, os Miranda Henriques, os Vidal de Negreiros...). Finalmente, e no que respeita à dimensão cultural de todo este processo, para Alencastro a Companhia de Jesus terá fornecido a justificação ideológica para a escravização de negros e para a proteç̧ão dos indígenas - uma conclusão que terá de ser confrontada com as recentes investigações de Charlotte de Castelnau e de Carlos Zeron acerca dos efeitos culturais da missionação em terras brasileiras, desde os finais de Quinhentos até ao primeiro quartel do século XVII ${ }^{84}$.

Este é um entre vários outros exemplos que poderiam ser apresentados para ilustrar os avanços da historiografia que incide na história político-administrativa do Brasil dos Habsburgo e dos primeiros Bragança. O período compreendido

82 Cfr. Canabrava, Alice: $O$ comércio português no Rio da Prata, 1580-1640, São Paulo, Universidade, 1944; Reparaz, Gonçalo: Os portugueses no Perú nos séculos XVI e XVII, Lisboa, Tip. Casa Portuguesa, 1967; BARRIERA, Darío : Vers une bistoire politique configurationnelle. Conquérants, familles et rapports de pouvoir dans une ville aux confins de l'Empire espagnol (Santa Fé, Rio de La Plata, XVI-XVIIe siècles), tese defendida na École des Hautes Études en Sciences Sociales, 3 vols., Paris, 2002.

${ }_{83}$ Sobre este tema, consulte-se RuSSELL-WOOD, A. J. R.: «Iberian Expansion and the issue of Black Slavery: changing Portuguese Attitudes, 1440-1770", The American Historical Review, 83 (1978) pp. 16-42; KNIGHT, Franklin W.: «Slavery and lagging capitalism in the Spanish and Portuguese American Empires, 1492-1713" in Solow, Barbara L. (org.): Slavery and the rise of the Atlantic System, Cambridge, Cambridge University Press, 1991, pp. 62-74.

${ }^{84}$ Castelnau, Charlotte de \& Zeron, Carlos, «Une mission glorieuse et de profit. Réforme missionnaire et économie sucrière dans la province jesuite du Brésil au début du 17e siècle», Revue de Synthèse, 4e. Serie, t. 120, n. 2-3 (199) pp. 14 segs. 
entre 1621 e 1654 - ou seja, os anos da guerra neerlandesa - tem sido, sem dúvida, o mais privilegiado pelos estudiosos, com uma ênfase especial para os trabalhos de Evaldo Cabral de Mello e para as investigações de Pedro Puntoni85. Outro contributo importante é o de Guida Marques, historiadora que prepara actualmente uma dissertação de doutoramento sobre a administração do Brasil no primeiro quartel de Seiscentos, um período menos conhecido mas nem por isso menos importante da história do Brasil colonial sob os Habsburgo. Privilegiando a dimensão comunicacional da actividade político-administrativa da Coroa em terras brasileiras, o estudo de Guida Marques incide sobre as formas de comunicação entre órgãos administrativos, o papel estratégico da informação; os expedientes de vigilância e de controle que foram implementados, etc. Encontrase também em curso - através dos trabalhos de Guida Marques, de Edval de Souza Barros, de Erik Myrup, de Gilson Reis, entre outros - a caracterização do papel desempenhado pelos sucessivos órgãos palatinos que lidaram com matérias brasileiras, a saber, o Conselho da Índia criado no tempo de D. Filipe II de Portugal, a Junta da Fazenda ${ }^{86}$, a Junta de Pernambuco, o Conselho Ultramarino e a Junta do Comércio, para além de outras instituições de menor projecção.

No que especificamente respeita ao lugar do Brasil no quadro das relações entre Portugal e a Monarquia Hispânica, o desvendar de novos corpora documentais - com destaque para o decisivo contributo do «Projecto Resgate» (identificação e reprodução da documentação sobre o Brasil-colónia dispersa pelo mundo) - também foi determinante. O grande manancial de dados que tem sido revelado permitiu efectuar uma avaliação mais precisa do papel do Brasil na relação estabelecida entre a Coroa Portuguesa e os monarcas Habsburgos. Questionou-se, desde logo, um tópico muito enraizado; não só na historiografia mas sobretudo no senso comum: a tradicional distinção entre o modelo colonizador luso - onde alegadamente predominaria uma economia baseada em explorações rurais e no escravismo - e aquele que se desenvolveu na América Espanhola, por exemplo no México no Peru, territórios que contavam com grandes concentrações populacionais de indígenas e minas de prata. Trabalhos recentes têm contribuído para matizar este tópico ${ }^{87}$.

Os recentes desenvolvimentos historiográficos têm também permitido uma mais correcta avaliação do peso político do Brasil, chamando a atenção para o facto de, desde bastante cedo, o potencial do espaço brasileiro ter sido pressentido pelos governantes ibéricos. Sabe-se hoje que datam do reinado de D. João III as primeiras propostas de transferência ou retirada da corte lusa para a

85. Mello, Evaldo Cabral de, O Negócio do Brasil. Portugal, os Países Baixos e o Nordeste (16411669), Lisboa, CNCDP, 2001.

86 Martïn GutiÉrrez, Diego: La Junta de Hacienda de Portugal, Pamplona, Newbook, 1996.

${ }_{87}$ Veja-se os comentários tecidos por SCHAUB, Jean-Frédéric, sobre este ponto, em «Hacia una historiografía eurocolonial. América portuguesa y Monarquía Hispánica» in AA. VV., Los virreinatos americanos, Actas do Congresso Internacional, Madrid, Novembro de 2002, Madrid, Centro de Estudios Constitucionales (no prelo).

Hispania, LXIV/1, núm. 216 (2004) 117-156 
América do Sul, para aí ser estabelecido o centro governativo de uma nova unidade política ${ }^{88}$. Sabe-se, também, que a centralidade da América Portuguesa se acentuou a partir do momento em que a Coroa lusa foi agregada à Monarquia Hispânica, e que uma das razões para o aumento da importância deste território, no quadro da estratégia ultramarina dos Habsburgo espanhóis, terá sido o facto de ele ter sido visto como uma primeira linha de defesa contra ataques dirigidos ao coração das Índias de Castela. O peso político do Brasil também esteve bem patente no investimento efectuado pelos monarcas Habsburgo tanto na reforma do seu dispositivo administrativo, quanto no empenho com que Filipe IV lidou com a ameaça neerlandesa ${ }^{89}$. Depois de 1640 , a importância do Brasil continuou bem presente, sobretudo se tivermos em conta que os diplomatas portugueses usaram este território como «moeda de troca» nas negociações para alcançar o reconhecimento internacional da sua secessão da Monarquia Hispânica - à semelhança do que sucedera nas negociações encetadas pelos "Antonianos», logo após 1581 , junto das coroas inglesa e francesa ${ }^{90}$.

Ainda no que toca ao impacte da agregação da Coroa lusa nos domínios dos Habsburgo, cumpre ter em conta o importante tema da integração entre América Espanhola e América Portuguesa. Tal como sucedeu na parte oriental dos impérios ibéricos ${ }^{91}$, após 1581 também no Atlântico é possível detectar vários sinais de integração, em especial em duas áreas: a comercial e a militar. Quanto aos laços comerciais, aprofundaram-se as pré-existentes rotas de ligação entre diversos pontos da costa africana e as Índias Espanholas, sobretudo relacionadas com o fornecimento de escravos ${ }^{92}$. Desenvolveram-se, também, os laços entre a América Portuguesa e as Índias Espanholas, como por exemplo o eixo Rio de Janeiro-Buenos Aires, ou as ligações entre o Maranhão, o Alto Amazonas $^{93}$ e as possessões caribenhas da Coroa de Castela. No que concerne à

${ }^{88}$ Cfr. Mello, Evaldo Cabral de: Um imenso Portugal. História e Historiografia, São Paulo, Editora 34, 2002, pp. 63 segs.

89 SCHWARTZ, Stuart B.: «Luso-Spanish Relations in Habsburg Brazil», The Americas, 34 (1968) pp. 33-48. E, também, STELLA, Roseli Santaella: O domínio espanbol no Brasil..., cit., 2000.

90 MARques, Guida: «La dimension atlantique de l'opposition antonienne au pouvoir des Habsbourg et l'enjeu brésilien (1580-1640)», Anais de História de Além-Mar, IV (2003), pp. 213-246.

91 VAlladares, Rafael: Castilla y Portugal en Asia (1580-1680). Declive imperial y adaptación, Lovaina, Leuven University Press, 2001.

92 Consulte-se in genere os trabalhos de VenturA, Maria da Graça (coord.): A União Ibérica e o mundo Atlântico. Segundas Jornadas de História Ibero-Americana, Lisboa, Colibri, 1997; Esteves, Maria Luísa: «Para o estudo das relações comerciais de Angola com as Indias de Castela e Génova no período da restauração (1640-1668)», Studia, nº 51 (1992), pp. 29-60; CORTÉS LÓPEZ, José Luis: «La importancia de la esclavitud en la expansion portuguesa en Africa y su repercusión en el mundo hispánico" in CARABIAS TORREs, Ana Maria (org.): Las relaciones entre Portugal e Castilla en la Época de los Descobrimientos y de la Expansión Colonial, Salamanca, Universidad, 1994, pp. 1249-1269.

93 DOMINGUES, Ângela: "O reconhecimento do "Rio Grande": as primeiras viagens de Espanhóis e Portugueses pelo País das Amazonas» in AA. VV., Portugal-Brasil. Memórias e Imaginário, Lisboa, GTMECDP, 2000, pp. 5-12. 
administração militar, as necessidades de defesa contra inimigos comuns cedo impuseram uma visão integrada e de solidariedade entre a América Portuguesa e a América Espanhola. Os estudos já citados de Evaldo Cabral de Mello, de Pedro Puntoni, de Roseli Santaella Stella, de Rafael Valladares e, mais recentemente, de Guida Marques, comprovam o que acabámos de afirmar. A guerra contra os neerlandeses no Nordeste brasileiro, além de ter dado força àqueles que pugnavam pela organização de uma série de empreendimentos militares em que participassem soldados oriundos de diversos pontos da Monarquia, contribuiu também para reforçar a opinião daqueles que pensavam, de forma integrada, a defesa das possessões americanas das coroas ibéricas ${ }^{94}$.

No entanto, é importante frisar que esta visão integrada esteve longe de ser consensual, tendo sido forte a resistência contra as abordagens administrativas em que os âmbitos jurisdicionais das suas coroas se confundiam. A visão particularista subsistiu entre alguns portugueses que recearam ver o seu espaço imperial invadido por dignitários, oficiais e negociantes oriundos de outros pontos da Monarquia dos Habsburgo. Contudo, a filiação nacional não explica muitas das tomadas de posição sobre este tema, já que é também possível encontrar numerosos exemplos de portugueses entusiasticamente favoráveis a um aprofundamento da integração entre as possessões americanas de Castela e as de Portugal. Da mesma forma, convém evitar a visão simplista de uma Castela invariavelmente centralizadora e sempre empenhada em incorporar novos territórios. $\mathrm{Na}$ verdade, sabemos hoje que, nalguns casos, foram os próprios órgãos da administração central castelhana os primeiros a travar um aprofundamento da integração entre os dois impérios na América meridional, demonstrando um receio simétrico àquele que era nutrido por alguns portugueses, ou seja, receando a invasão, por parte de «hordas» de portugueses, das áreas de influência hispânica, com a consequente dispersão de monopólios, de privilégios e de poder ${ }^{95}$.

A revolta de 1640 eclode num momento em que estava em curso este diálogo entre os partidários de uma maior integração e aqueles que actuavam no sentido particularista. Para além de ter rompido - pelo menos temporariamente algumas das rotas anteriormente desenvolvidas (por exemplo o eixo Rio de Janei-

94 SCHWARTZ, Stuart B.: «A jornada dos vassalos: poder real, deveres nobres e capital mercantil antes da Restuaração, 1624-1640» in Da América Portuguesa ao Brasil. Estudos Históricos, Lisboa, Difel, 2003, pp. 143-184.

95 Cfr. SCHWARTZ, Stuart B.: «Pânico nas Índias. A ameaça portuguesa ao Império espanhol, 1640-1650» in Da América Portuguesa ao Brasil..., cit., 2003, pp. 185-216. Para uma compreensão deste problema à escala mais geral da Monarquia Hispânica, veja-se o excelente ensaio de THOMPSON, I. A. A.: «Castile, Spain and the monarchy: the political community from 'patria natural' to 'patria nacional'» in KAGAN, R. \& PARKER, G. (orgs.): Spain, Europe and the Atlantic world. Essays in bonour of John $H$. Elliott, Cambridge, Cambridge University Press, 1995, pp. 125-159; acerca desta temática consulte-se o nosso "Política e identidades corporativas no Portugal de D. Filipe I» in AA. VV., Estudos em Homenagem a Joäo Francisco Marques, Porto, Faculdade de Letras da Universidade do Porto, 2002, vol. 1, pp. 275-306.

Hispania, LXIV/1, núm. 216 (2004) 117-156 
ro-Buenos Aires), o movimento separatista português foi aproveitado, do lado Hispânico, por aqueles que nutriam algum ressentimento pela crescente entrada de lusos nos circuitos da Monarquia. Rafael Valladares assinalou recentemente que a revolta de 1640 foi um bom pretexto para a expulsão dos chamados «infiltrados lusos» estabelecidos nas colónias espanholas. Quanto aos mercadores de Sevilha, acolheram favoravelmente a revolta de 1 de Dezembro, pois proporcionava uma boa justificação para se livrarem dos concorrentes lusos ${ }^{96}$.

Contudo, é inegável que a ruptura de 1640 acarretou prejuízos avultados, e vários homens de negócio - Portugueses e Hispânicos - sofreram prejuízos devido ao corte de relações que se seguiu à revolta, o mesmo se podendo dizer de algumas regiões da América espanhola, agora privadas de importantes zonas de abastecimento de escravos. Em Buenos Aires a situação tornou-se particularmente complicada, pois à escassez de escravos somou-se a interrupção de contactos comerciais com as áreas meridionais brasileiras ${ }^{97}$. Ainda assim, o tráfico clandestino prosseguiu, não só com o sul do Brasil, mas também com mercadores neerlandeses. Quanto aos círculos financeiros, Rafael Valladares notou que após 1640 um grupo de banqueiros portugueses em Madrid - com Duarte Fernandes à cabeça - moveu influências para que fossem organizadas missões junto das autoridades luso-brasileiras e luso-angolanas para as convencer a permanecerem fiéis aos Habsburgo ${ }^{98}$. Segundo Valladares, o plano integrava-se na política de bloqueio económico desenvolvida por Filipe IV, cujo intuito era desviar o tráfico saído desses territórios e canalizá-lo para os portos da Monarquia Hispânica, a fim de asfixiar a economia portuguesa.

A par da Monarquia Hispânica, o «Tempo dos Flamengos» tem sido outra das áreas de eleição da recente historiografia. A partir das pistas lançadas pelo clássico livro de José Antônio Gonsalves de Mello, o Brasil holandês tem sido objecto de uma atenção inusitada, em especial da parte de Evaldo Cabral de Mello e de Pedro Puntoni, estudando temas como o modelo político-administrativo desenvolvido pelos neerlandeses, a integração do Nordeste açucareiro nos circuitos comerciais e financeiros das Províncias Unidas, o papel desempenhado pelos Judeus e pelos Cristãos-Novos, ou, ainda, a postura dos neerlandeses face ao escravismo 99 . Tem-se constatado, também, que alguns dos governantes neerlandeses se distinguiram por uma muito vincada dimensão projectual ao nível político, em particular a figura central de João Maurício de Nassau ${ }^{100}$.

\footnotetext{
96 VALLADARES, Rafael: «El Brasil y las Indias españolas durante la sublevación de Portugal (1640-1668)», Cuadernos de Historia Moderna, 14 (1993) pp. 151-172.

. 97 VALLADARES, Rafael: «El Brasil y las Indias españolas..., cit., 1993, pp. 162 segs.

98 VALLADARES, Rafael: «El Brasil y las Indias españolas..., cit., 1993, pp. 155 segs.

99 PUntoni, Pedro: A Mísera Sorte. A Escravidäo Africana no Brasil Holandês e as Guerras do Tráfico no Atlântico Sul, 1621-1648, São Paulo, Hucitec, 1999.

${ }^{100}$ MeLO, Ana Vasconcelos e: Imagens do Nordeste brasileiro no século XVII. Um discurso visual de apropriação colonial, Tese de Mestrado em História da Arte, Universidade Nova de Lisboa, 2000.
} 
A Evaldo Cabral de Mello devemos páginas de antologia sobre alguns temas fundamentais do período neerlandês, mas não só: em primeiro lugar, demonstrou que a guerra neerlandesa foi um lugar de experimentação de novas técnicas militares, as quais influenciaram posteriormente a arte da guerra na Europa. Cabral de Mello procedeu, também, a uma minuciosa reconstituição da chamada "Querela dos Engenhos", ou seja, a disputa que, na década de 1660, opôs os antigos proprietários aos novos possuidores dos engenhos localizados em zonas ocupadas pelos neerlandeses ${ }^{101}$. Por último, o mesmo Cabral de Mello estudou o lugar de Pernambuco nas negociações diplomáticas que se seguiram à revolta de 1640 , assim como o papel desempenhado por este conflito no processo de reforço da identidade política pernambucana, processo esse que teve o seu momento culminante na segunda metade de Seiscentos ${ }^{102}$.

\section{AS ELITES LUSO-BRASILEIRAS E A POLÍTICA EM TERRAS TROPICAIS}

Naquela fase inicial do empreendimento colonizador, a política, nas terras sul-americanas, jogava-se essencialmente em torno do controle dos recursos materiais e simbólicos disponíveis. Embora não exista ainda um consenso quanto à melhor palavra para designar os protagonistas da dinâmica política da América Portuguesa - «colonos»?; «brasileiros»?; «brasílicos»? -, dispomos já de estudos monográficos sobre a actuação de figuras que desempenharam funções de relevo na administração territorial, em especial sobre alguns representantes da Coroa em terras brasílicas. Trabalhos como os já citados de Evaldo Cabral de Mello e de Luiz Felipe de Alencastro, mas também os estudos de Maria Fernanda Bicalho ${ }^{103}$, de Francisco Bethencourt ${ }^{104}$, de Maria de Fátima Gouvêa ${ }^{105}$, entre outros, têm demonstrado que os vice-reis e os governadores, enquanto representantes da Coroa, gozavam de uma enorme margem de autonomia, realidade que obriga a matizar a imagem de um império fortemente centralizado. Merece referência, também, a linha de estudos dedicada à história social das elites políticas, onde Nuno Gonçalo Monteiro, Mafalda Soares da Cunha ${ }^{106}$ e Maria Fernanda Oli-

101 Mello, Evaldo Cabral de: Olinda Restaurada..., cit., 1998, pp. 381 segs.

102 Mello, Evaldo Cabral de: Rubro Veio. O imaginário da restauração pernambucana, $2^{a}$ edição revista e aumentada, Rio de Janeiro, Topbooks, 1997.

103 BICALHO, Maria Fernanda: «Centro e periferia: pacto e negociação política na administração do Brasil Colonial", Leituras. Revista da Biblioteca Nacional, 6 (2000) pp. 17-40.

104 Bethencourt, Francisco: "O complexo Atlântico" in Bethencourt, F. \& CHAudhurI, K. (dirs.): História da Expansão Portuguesa, Lisboa, Círculo de Leitores, 1998, vol. II, pp. 315-342.

${ }^{105}$ Cfr. o excelente ensaio de GoUvÊA, Maria de Fátima: «Poder político e administração na formação do complexo atlântico português (1645-1808)» in FRAGOSO, João, BICALHO, Maria Fernanda e GouvÊA, Maria de Fátima (orgs.): O Antigo Regime nos Trópicos.., cit., 2001, pp. 287-315.

106 CUNHA, Mafalda Soares da: «Os governadores coloniais» in MONTEIRO, Nuno G., CUNHA, Mafalda Soares da, e CARDim, Pedro (orgs.): Optima Pars. As Elites do Antigo Regime no espaço Iberoamericano, Lisboa, Imprensa de Ciências Sociais (no prelo).

Hispania, LXIV/1, núm. 216 (2004) 117-156 
val ${ }^{107}$ têm investigado questões como o recrutamento, a hierarquia e a qualidade de nascimento dos membros das diversas elites actuantes no quadro imperial. Tirando o partido da prosopografia, estes estudiosos reconstituíram as opções dos diversos grupos sociais face às várias oportunidades de serviço proporcionadas pela Coroa. Tal abordagem tem permitido identificar as prioridades da Coroa e as linhas de força da sua actuação, numa perspectiva tanto diacrónica como sincrónica. A neurálgica questão do processo de escolha dos governadores coloniais também tem sido abordada por Nuno Monteiro ${ }^{108}$ e por Mafalda Soares da Cunha ${ }^{109}$, em trabalhos onde se torna bem claro que se tratava de uma selecção que seguia vias muito diversificadas, e que só em alguns casos era antecedida por uma consulta ou parecer de órgãos como o Conselho da Fazenda, o Conselho da Índia ou o Conselho Ultramarino.

Graças às citadas investigações de Mafalda Soares da Cunha, sabemos hoje que para os principais postos de governo a Coroa chamava membros da aristocracia, se bem que, até bastante tarde, o serviço na Índia tenha continuado a ser muito mais valorizado pela Coroa e, logo, mais atractivo para a grande nobreza. Além de demonstrarem que o serviço desempenhado na parte Oriental do império era muito melhor remunerado do que os cargos exercidos no Atlântico, os estudos de Mafalda Soares da Cunha para o período seiscentista, e os de Nuno Gonçalo Monteiro ${ }^{110}$ para o século XVIII, sugerem também que o serviço militar constituiu a principal via de nobilitação no quadro da governação colonial, se bem que a guerra fosse avaliada de uma forma muito diferenciada: a chamada "guerra viva» (caso da "guerra holandesa») era muito mais valorizada do que a "guerra de pegar índio» ou do que a «guerra dos Palmares». Estas últimas, e sobretudo a participação em «Bandeiras», podiam funcionar, até, como factor de desqualificação social.

Em face dos dados até agora compilados sobre o conjunto do oficialato régio, uma coisa parece certa: no tocante à remuneração de serviços a Monarquia não necessitou de fazer uma grande transferência de recursos para remunerar os serviços prestados pelos seus vassalos na América do Sul. Em regra, os naturais do Brasil eram recompensados com cargos, dignidades ou honras sul-americanas, e até ao final de Seiscentos só poucos ascenderam ao ponto de desempenharem um

107 OlIVAL, Maria Fernanda: As Ordens Militares e o Estado Moderno. Honra, mercê e venalidade em Portugal (1641-1789), Lisboa, Estar, 2001.

108 MONTEIRO, Nuno Gonçalo: «Trajectórias sociais e governo das conquistas: Notas preliminares sobre os vice-reis e governadores-gerais do Brasil e da Índia nos séculos XVII e XVIII" in Fragoso, João, BICALHO, Maria Fernanda \& GouvÊA, Maria de Fátima (orgs.): $O$ Antigo Regime nos Trópicos..., cit., 2001, pp. 249-284

109 CUNHA, Mafalda Soares da: «Do Brasil à Metrópole. Efeitos sociais (séculos XVII-XVIII)» in Cunha, Mafalda Soares da (coord.): Do Brasil à Metrópole. Efeitos Sociais, Évora, Universidade, 2001, pp. 9-14.

110 MonTEiro, Nuno Gonçalo: «A Corte, as províncias e as conquistas: centros de poder e trajectórias sociais no Portugal Restaurado (1668-1750)» in VenTURA, Maria da Graça (coord.): $O$ Barroco e o Mundo Ibero-Americano, Lisboa, Colibri, 1998.

Hispania, LXIV/1, núm. 216 (2004) 117-156 
papel de primeira importância na alta política de Madrid ou de Lisboa. Quanto ao perfil social desses homens, estudos recentes demonstram que, no século XVII, ainda é possível encontrar alguns dignitários que, devido aos serviços prestados no Brasil, conseguiram chegar à nobreza de corte, como Duarte Coelho, Matias de Albuquerque ou Salvador Correia de Sá. No século XVIII, porém, já não se verificam tais trajectórias de ascensão na hierarquia social ${ }^{111}$.

Importante é, também, a caracterização aprofundada do dispositivo judicial, com destaque para os grandes tribunais. A Relação da Bahia, e a mais tardia Relação do Rio de Janeiro, enquanto entidades que representavam a Justiça régia no território sul-americano, gozavam, também elas, de grande autonomia, tal e qual como sucedia com os tribunais do reino aos quais estavam equiparados - a Casa da Suplicação e a Casa do Cível. Apesar dos estudos de S. Schwartz, de Arno .Wehling ${ }^{112}$ e de José Subtil ${ }^{113}$ sobre esta temática, trata-se de uma área ainda grandemente por explorar.

Além dos grandes tribunais, não devemos perder de vista que a administração judicial da Coroa passava igualmente pelos oficiais de justiça dispersos pelos territórios sul-americanos, figuras que também têm sido objecto de uma atenção aturada ${ }^{114}$. No que concerne aos magistrados e à generalidade dos letrados que se encontravam ao serviço da Coroa, os trabalhos de S. Schwartz continuam, ainda hoje, a ser determinantes, demonstrando o quão fortes eram os laços estabelecidos entre o desembargadores e a população local. Mais recentemente, as investigações de José Subtil ${ }^{115}$ e de Nuno Camarinhas ${ }^{116}$ têm concorrido para um mais completo entendimento do perfil social do universo letrado, demonstrando, por exemplo, que os altos cargos da magistratura eram monopolizados por reinóis; que existiam «dinastias» de juízes no serviço admi-

111 MONTEIRO, Nuno Gonçalo: «Trajectórias sociais e governo das conquistas: Notas preliminares sobre os vice-reis e governadores-gerais do Brasil e da Índia nos séculos XVII e XVIII» in Fragoso, João, BICAlHo, $\mathrm{M}^{\mathrm{a}}$ Fernanda \& GouvÊA, $\mathrm{M}^{\mathrm{a}}$ Fátima (orgs.): $O$ Antigo Regime nos Trópicos..., cit., 2001, pp. 249-284.

112 Wheling, Arno, e Wheling, Maria José: Formaşāo do Brasil colonial, Rio de Janeiro, 1999.

113 SUBTIL, José: "Os ministros do rei no poder local, ilhas e ultramar (1772-1826)», Penélope. Revista de História e Ciências Sociais, $\mathrm{n}^{\circ} 27$ (2002) pp. 37-58; também de SUBTIL, veja-se, «Os Desembargadores em Portugal (1640-1820)" in MONTEIRo, Nuno G., CunHA, Mafalda Soares da, e Cardim, Pedro (orgs.): Optima Pars. As Elites do Antigo Regime no espaço Ibero-americano, Lisboa, Imprensa de Ciências Sociais (no prelo).

114 Salgado, Graça (org.): Fiscais e Meirinhos. A Administração no Brasil Colonial, Rio de Janeiro, Nova Fronteira, 1985, compare-se com os trabalhos de Tamar HeRZOG, La daministración como un fenómeno social. La justicia penal de la ciudad de Quito (1650-1750), Madrid, CEC, 1995, idem, Los ministros de la Audiencia de Quito (1650-1750), Quito, Libri Mundi, 1995.

115 Cfr. SubTIL, José: "Os ministros do rei no poder local, ilhas e ultramar (1772-1826)", Penélope. Revista de História e Ciências Sociais, $\mathrm{n}^{\circ} 27$ (2002) pp. 37-58.

116 CAMARinhas, Nuno: Letrados e lugares de letras. Análise prosopográfica do grupo dos juristas letrados em Portugal nos séculos XVII e XVIII, tese de mestrado, Instituto de Ciências Sociais da Universidade de Lisboa, 2000 (policopiado).

Hispania, LXIV/1, núm. 216 (2004) 117-156 
nistrativo do Brasil; e que foram poucos os naturais da América do Sul que terminaram a sua carreira no reino.

De qualquer modo, importa não esquecer que, em comparação com a América Espanhola, o Brasil contava com um dispositivo administrativo menos desenvolvido e com um nível de institucionalização mais limitado - basta lembrar a tardia criação do primeiro Vice-Reinado no Brasil; a existência, até meados de Setecentos, de apenas um tribunal superior em terras brasileiras; ou, ainda, o facto de América portuguesa jamais ter contado com uma universidade, ao contrário do que sucedeu na América espanhola ${ }^{117}$. $O$ aparelho administrativo da Coroa cobria somente uma exígua faixa do território, e só no final do século XVII surgem os primeiros «juízes de fora» em câmaras brasileiras. Quanto às Casas dos Vinte e Quatro, em pleno século XVII apenas existiam num número reduzido de câmaras.

A par das instituições judiciais e dos seus agentes, é fundamental ter em conta que a eficácia dos modelos de organização comunitária que os europeus impuseram dependia grandemente da acção das autoridades mais estreitamente articuladas com os "naturais" das terras sul-americanas: antes de mais, os capitães-donatários ${ }^{118}$ e os governadores de capitanias. Além deles, a estrutura eclesiástica e as suas técnicas de disciplinamento também se revelaram determinantes para a imposição de um modelo organizativo "Ocidental"119. Por fim, a ordem dependia, também, da fundamental acção coesiva levada a cabo pelas câmaras municipais.

Maria Fernanda Bicalho assinou o mais recente estudo sobre o poder municipal na América Portuguesa ${ }^{120}$. Na linha dos trabalhos seminais de Charles Boxer, demonstrou que as autoridades municipais funcionaram como centros logísticos de apoio à organização do território e à criação de um enquadramen-

117 Sobre as implicações desta questão, cfr. SCHWARTZ, Stuart: «The Formation of a Colonial Identity in Brazil" in CANNY, Nicholas \& PADGEN, Anthony (orgs.): Colonial Identity in the Atlantic World, 1500-1800, Princeton, Princeton University Press, 1989, pp. 15 segs.

118 Veja-se, maxime, de Saldanha, António Vasconcelos de: As capitanias do Brasil. Antecedentes, desenvolvimento e extinção de um fenómeno Atlântico, $2^{\mathbf{a}}$ ed., Lisboa, CNCDP, 2001; consulte-se também, de Bethencourt, F. , «As Capitanias» in Bethencourt, F. \& ChAudhuri, K. (dirs.): História da Expansão Portuguesa, Lisboa, Círculo de Leitores, 1998, vol. I, pp. 341-352.

119 Cfr. SousA, Luís Filipe Marques de: «Frei Cristóvão de Lisboa e a sua correspondência com Manuel Severim de Faria, seu irmão» in AA. VV., Congresso de História no IV Centenário do Seminário de Évora, Actas, volume II, Évora, Instituto Superior de Teologia, 1994; BosCHI, Caio: «O enquadramento religioso" in BeTHENCOURT, F. e CHAUDHUR, K. (dirs.): História da Expansão Portuguesa, Lisboa, Círculo de Leitores, vol. II, 1998, pp. 388 segs.; também de BosCHI, Caio: «Traços de cristianização no Atlântico Sul Seiscentista» in PIMENTEL, Maria do Rosário: Portugal e Brasil no advento do Mundo Moderno, Lisboa, Edições Colibri, 2001, pp. 245-256; e, de PALOMO, Federico: «"Disciplina christiana" Apuntes historiográficos en torno a la disciplina y el disciplinamiento social como categorías de la historia religiosa de la alta edad moderna", Cuadernos de Historia Moderna, 18, 1997, p. 119-136.

${ }^{120}$ BICALho, Maria Fernanda: $A$ Cidade e o Império. O Rio de Janeiro no século XVIII, Rio de Janeiro, Civilização Brasileira, 2003. 
to administrativo de feição europeia. Para Bicalho, as Câmaras, enquanto dispositivo presente em todos os territórios controlados pela monarquia lusa, foram o verdadeiro pilar do império, embora esta estudiosa não deixe de frisar que as câmaras assumiram configurações muito diferentes umas das outras, devido à diversidade dos locais onde estavam inseridas e dos interesses daqueles que em torno delas gravitavam. Além disso, a mesma Maria Fernanda Bicalho recorda que as câmaras das cidades. onde se estabeleciam os representantes da Coroa costumavam ver limitados os seus poderes e a sua autonomia.

No que toca ao universo político local, à semelhança do que sucedia no reino, sabemos hoje que a Coroa favoreceu a oligarquização das instituições, confiando a manutenção da ordem a um conjunto restrito de famílias preponderantes nas principais povoações e cidades ${ }^{121}$. Como é conhecido, os "poderosos» lusobrasileiros costumavam estruturar-se em grupos: no Rio de Janeiro do século XVII, por exemplo, pontificavam dois clãs principais, o dos Correia de Sá e o dos Manuéis; em Pernambuco, é famosa a família Albuquerque e as suas várias ramificações (Albuquerque Maranhão, Coelho de Carvalho, Cavalcanti...); quanto ao representante da Coroa, também ele podia formar o seu próprio bando.

Num trabalho recente, João Fragoso, Maria Fernanda Bicalho e Fátima Gouvêa chamaram a atenção para o peculiar regime de troca de bens e serviços estabelecido no seio de muitas cidades coloniais brasileiras, sustentando que essa troca jamais perdia de vista aquela que era a mais transcendente prioridade: a manutenção do status quo. Tal regime - que estes investigadores brasileiros apelidaram de «economia do bem comum» - implicava uma distribuição profundamente desigual, favorecendo a reprodução da minoria que já se encontrava no poder e contribuindo para a sua perpetuação numa posição dominante. Além disso, tudo leva a crer que tais grupos lograram acumular um volume muito considerável de riqueza desde, pelo menos, os finais de Quinhentos ${ }^{122}$.

Em certos momentos estes bandos que dividiam as sociedades locais americanas entreteciam ramificações que chegavam até a afectar a "alta política", influenciando, inclusive, os processos de decisão governativa na corte de Madrid ou de Lisboa. É nesse sentido que devemos encarar a actuação de Salvador Correia de Sá no Conselho Ultramarino, a partir de 1652, ou a influência exercida nos círculos régios pela família Pernambucana dos Albuquerque Coelho, ou por figuras como João Fernandes Vieira ou André Vidal de Negreiros, como se sabe dois homens com fortes interesses escravocratas em Angola.

121 RuSSELL-WoOD, A. J. R. (org.): Local Government in European Overseas Empires, 1450-1800, Brookfield, Ashgate, 1999; BICALHO, Maria Fernanda: «O que significava ser cidadão nos tempos coloniais» in ABREU, Martha \& SOIHET, R. (orgs.): Ensino de História. Conceitos, temáticas e metodologia, Rio de Janeiro, Casa da Palavra, 2003, pp. 139-151.

122 Fragoso, João, GouvêA, Maria de Fátima e BICALHo, Maria Fernanda «Uma Leitura do Brasil Colonial. Bases da materialidade e da governabilidade no Império», Penélope. Revista de História e Ciências Sociais, 23 (2000) pp. 67-88.

Hispania, LXIV/1, núm. 216 (2004) 117-156 
Porém, e como seria de prever, nessa política local dividida em bandos e em parentelas, os conflitos eram frequentes, e tal situação afectava, por vezes, os interesses da Coroa. O mesmo se pode dizer das incursões de rivais europeus, como por exemplo as expedições francesas ${ }^{123} \mathrm{e}$, sobretudo, as investidas dos neerlandeses. Como demonstrou Francis Dutra ${ }^{124}$, em certos casos a guerra contra os neerlandeses terá sido aproveitada pelo colonato luso-brasileiro para recuperar posições contra a influência da Coroa ou contra algum bando concorrente. $\mathrm{O}$ mesmo F. Dutra lembra que a devastação provocada pela guerra na Bahia foi o motivo invocado por Matias de Albuquerque, em 1624, para persuadir o rei a suspender a Relação da Bahia. O tribunal foi mesmo suspenso em 1626, para só retomar funções em 1652.

Todavia, e a pesar de, por vezes, desempenharem um papel desestabilizador, a verdade é que, ao mesmo tempo, os grupos de poderosos eram imprescindíveis para a administração territorial, pois era graças aos laços de solidariedade que uniam os seus membros que se tornava possível conferir coesão a essas comunidades tão pouco estruturadas e dotadas de um tão fraco enquadramento administrativo da Coroa. Funcionando segundo uma lógica de família alargada, tais grupos apropriaram-se - formal ou informalmente - de um grande número de funções que hoje classificaríamos como «públicas», chegando ao ponto de desenvolver os seus próprios exércitos particulares. A sua preponderância tornou-se tão acentuada que lograram realizar, desde finais de Quinhentos, uma muito significativa acumulação endógena de riqueza, riqueza essa proveniente em boa medida do tráfico mercantil com outros pontos do Atlântico, incluindo a Europa ${ }^{125}$. Longe de ser exclusiva das terras sulamericanas controladas pelos portugueses, tudo indica que esta situação é muito semelhante à que se pode encontrar em alguns dos domínios americanos da Monarquia Hispânica e, ainda, de certas partes da Europa.

Um tanto paradoxalmente, a situação de quase permanente conflito militar vivido na América do Sul durante. boa parte do século XVII acabou por proporcionar alguns proveitos à Coroa, pois a guerra permitiu ao poder régio justificar a concessão de amplos poderes militares a vários dos seus representantes. Assim, a pretexto do confronto militar a Coroa concedeu a diversos governado-

123 LESTRINGANT, Franck : Le Huguenot et le Sauvage. L'Amérique et la controverse coloniale en France, au temps des guerres de Religion, Paris, 1990; CouTO, Jorge: «O conflito luso-francês pelo domínio do Brasil até 1580" in VenturA, Maria da Graça Mateus (org.): Viagens e Navegantes no Atlântico Quinbentista, Lisboa, Colibri, 1996.

124 Dutra, Francis: «Centralization vs. donatarial priviledge: Pernambuco, 1602-1630» in Dauril Alden (org.), Colonial roots of modern Brazil, Los Angeles, University of California Press, 1973, pp. 19-60.

125 Fragoso, João e Florentino, Manolo: «A comunidade de mercadores do Rio de Janeiro e o mercado atlântico português na passagem do século XVIII para o XIX» in BASTOS, Cristiana, AlmeidA, Miguel Vale de \& FELDMAN-BIANCO, Bela (orgs.): Trânsitos coloniais: diálogos críticos lusobrasileiros, Lisboa, Imprensa de Ciências Sociais, 2002, pp. 321-342.

Hispania, LXIV/1, núm. 216 (2004) 117-156 
res-gerais uma extraordinaria potestas de cariz eminentemente militar, o que significa que a guerra proporcionou uma oportunidade à Coroa para implantar no terreno a sua estrutura militar. Em alguns momentos tal estrutura terá propiciado o reforço da autoridade régia a um nível territorial.

Outro pólo de poder a ter em conta são os chamados «senhores de engenho", cuja articulação de interesses gerava aquilo que os estudiosos designam de "Açucarocracia», um grupo que foi objecto de algumas pesquisas de grande fôlego, com destaque para as realizadas por S. Schwartz, por Vera Amaral Ferlini e por Evaldo Cabral de Mello. Apesar de dependerem das suas ligações com os comerciantes oceânicos que escoavam os seus produtos, tudo indica que estas grandes figuras locais foram os principais interlocutores da Coroa em terras sul-americanas, se bem que, ao mesmo tempo, tenham alimentado um mais ou menos permanente ressentimento face ao que consideravam ser as ingerências reinóis. No que toca às suas relações com o poder régio, reagiram ruidosamente contra aquilo que consideravam ser um trespasse do seu espaço de influência, mobilizando toda uma série de argumentos indigenistas e nativistas a fim de amplificarem as suas reivindicações políticas. Aliás, se há um traço que caracterize as elites brasílicas, bahiana e pernambucana, mas também a paulista, a carioca e a amazónica, é o facto de terem desenvolvido, muito precocemente, estratégias bastante hábeis para antepor aos representantes da Coroa os seus interesses e o seu imaginário ${ }^{126}$.

Ainda no que respeita aos sectores influentes em terras sul-americanas, o grupo dos comerciantes é outra área de investigação a ter em conta. Nos últimos anos, João Fragoso e Manolo Florentino caracterizaram exaustivamente as actividades dos comerciantes do Rio de Janeiro, assim como as suas ligações atlânticas ${ }^{127}$. Mais recentemente, Leonor Freire Costa estudou as redes comerciais estabelecidas entre os dois lados do Atlântico, concedendo uma especial atenção à Companhia Geral do Comércio do Brasil, criada em 1649 com a finalidade de implementar um novo sistema de transporte no Atlântico ${ }^{128}$. Porém, a par destas sondagens sobre a actividade mercantil costeira ou voltada para o mar, um outro tema que suscita cada vez mais atenção é, sem dúvida, o desenvolvimento dos circuitos internos de troca comercial e o papel desempenhado pelos «homens de negócio» em todo esse processo. Caio César Boschi e Júnia Furtado demonstraram, em diversos trabalhos, que os comerciantes de grosso trato oriundos da região de Minas tiveram um peso cada vez maior a

126 Mello, Evaldo Cabral de: Rubro Veio. O imaginário da restauraşäo pernambucana, Rio de Janeiro, Topbooks, 1997; e também, 0 nome e o sangue. Uma parábola familiar no Pernambuco colonial, $2^{\mathrm{a}}$ edição revista, Rio de Janeiro, Topbooks, 2000.

${ }^{127}$ FRAGOSO, João: «A Nobreza da República: notas sobre a formação da primeira elite senhorial do Rio de Janeiro (séculos XVI e XVII)", Topoi. Revista de História, 1 (2000) pp. 45-122.

128 Costa, Leonor Freire: «Pernambuco e a Companhia Geral do Comércio do Brasil», Penélope. Revista de História e Ciências Sociais, 23 (2000) pp. 41-65; e também, O transporte no Atlântico e a Companbia Geral do Comércio do Brasil (1580-1663), Lisboa, CNCDP, 2002.

Hispania, LXIV/1, núm. 216 (2004) 117-156 
partir do segundo quartel de Setecentos, primeiro na política local, depois fora dela ${ }^{129}$. O chamado «Ciclo do Ouro» e o crescimento do mercado interno terão concorrido também para acentuar a visibilidade política de Minas, assim como para conferir unidade aos até aí dispersos territórios da América Portuguesa. O ouro terá igualmente vincado a centralidade do Rio de Janeiro, uma cidade que se converteu, sucessivamente, em sede de vice-reinado, em capital do império e em centro do Brasil independente (veja-se, sobre este ponto, o estudo de Kirsten Schultz ${ }^{130}$ ).

No âmbito deste núcleo temático, é também fundamental ter em conta a intervenção dos negociantes no processo político, tanto sul-americano como cortesão. Os trabalhos de James Boyajian ${ }^{131}$ e de Nicolas Broens ${ }^{132}$, mas também os estudos atrás citados de Evaldo Cabral de Mello, de Luiz Felipe de Alencastro, de Jorge Pedreira e de Leonor Freire Costa demonstraram, claramente, que esses interesses mercantis se tornaram muito mais presentes na política cortesã a partir de finais de Quinhentos e ao longo de todo o século XVII. No que toca ao universo político das diversas regiões sul-americanas, a influência destes homens parece ter sido determinante, já que muitos mercadores chegaram mesmo a desempenhar formalmente cargos de natureza governativa e administrativa. Apesar dos impedimentos legislativos que existiam para vedar aos comerciantes a entrada na governação das câmaras municipais, sabe-se hoje que, em muitos casos, não existia alternativa, dado que, no quadro local, o número de gente nobre costumava ser muito diminuto, o que tornava quase inevitável o recurso a esse grupo sócio-profissional. Como assinalou Maria Fernanda Bicalho, este facto não é exclusivo da América Portuguesa, pois na generalidade das conquistas portuguesas regista-se uma notória «rarefacção de nobres» ${ }^{133}$.

Assim, tudo leva a crer que, fora da Europa, os endinheirados gozaram de mais oportunidades de ascensão social, ainda que tal contrariasse o sistema que imperava no reino ${ }^{134}$. No entanto, é fundamental não usar as categorias designadoras de grupos sociais de um modo reificado, pois tais grupos não eram

129 BosCHI, Caio C.: Os Leigos e o Poder..., cit., 1986. FuRTADo, Júnia Ferreira: Homens de Negócio. A interiorizaşão da metrópole e do comércio nas Minas Setecentistas, São Paulo, Hucitec, 1999.

130 SCHULTZ, Kirsten : Tropical Versailles. Empire, monarchy, and the Portuguese royal court in Rio de Janeiro, 1808-1821, Nova York, Routledge, 2001.

${ }^{131}$ Boyajian, James C.: Portuguese bankers at the Court of Spain 1626-1640, New Brunswick, Rutgers University Press, 1983.

132 Broens, Nicolas: Monarquía y capital mercantil. Felipe IV y las redes comerciales portuguesas, 1627-1635, Madrid, Universidad Autonoma, 1989.

133 BICALHO, Maria Fernanda: «Elites coloniais: a Nobreza da Terra e o governo das conquistas. História e Historiografia» in MonTeiro, Nuno G., CUNHA, Mafalda Soares da, e CARDIM, Pedro (orgs.): Optima Pars. As Elites do Antigo Regime no espaço Ibero-americano, Lisboa, Imprensa de Ciências Sociais (no prelo).

${ }^{134}$ Cfr. Novais, Fernando A. : "Condições de Privacidade na Colônia» in SouzA, Laura de Mello e (org.): Cotidiano e vida privada na América portuguesa, vol. I da História da Vida Privada do Brasil, colecção dirigida por NovaIS, Fernando A., São Paulo, Companhia das Letras, 1997, pp. 30 segs. 
realidades estáticas, tendo conhecido sucessivas recomposições internas. Os trabalhos de Leonor Freire Costa ${ }^{135}$ e de Jorge Pedreira ${ }^{136}$ mostram claramente que a maior parte dos «homens de negócio» a operar nas rotas sul-americanas eram recém-chegados ao Brasil, e que a maioria daqueles que enriqueciam acabavam por comprar terras, chegando mesmo alguns deles a abandonar a mercancia ${ }^{137}$. Todavia, a despeito destas "saídas" - que se podiam dever, também a falências -, em termos numéricos o grupo mercantil manteve uma assinalável estabilidade, graças à constante chegada de novos membros.

Por outro lado, e ainda no que toca à questão da mobilidade social, será importante evitar o efeito do maniqueísmo que subjaz à oposição entre o espaço europeu (onde tudo é rígido, bloqueado e regulado pela tradicional prática do poder) e a América (onde tudo é possível, onde impera a fluidez e ausência de normas) ${ }^{138}$. A esse respeito, poderá ser elucidativo o confronto entre o caso luso-brasileiro e os dados que Jean-Paul Zúñiga coligiu sobre Santiago do Chile no século XVII ${ }^{139}$. Num estudo que proporciona um excelente retrato do confronto entre a ideologia nobiliárquica castelhana e o ambiente colonial, Zúñiga demonstra que desse processo terão resultado novas realidades e novas fronteiras sociais, algumas delas tão ou mais rígidas do que as diferenças de estatuto social vigentes na Europa.

Por último, é importante não esquecer o papel coesivo desempenhado pela Coroa, tanto sob os Habsburgo quanto sob os primeiros Bragança. No que concerne ao século XVII, sabemos que os sucessivos monarcas deram passos decisivos no sentido da manutenção do domínio português em terras da América meridional. Por outro lado, e não obstante a proverbial rejeição de interferências vindas do exterior, há que ter em conta que a intervenção da Coroa nem sempre foi mal recebida. Guida Marques ${ }^{140}$ demonstrou recentemente que eram frequentes as iniciativas de câmaras brasileiras para chamar a atenção do Monarca Hispânico para a sua existência, a fim de serem integradas no mecanismo distributivo da Coroa e para desse modo poderem beneficiar das concessões régias. Os trabalhos de Cabral de Mello revelam, por seu turno, que as tensões entre os membros das elites locais e os comerciantes reinóis, ao arrastarem-se sem solução aparente, constituíram muitas vezes ocasiões propícias para

135 Costa, Leonor Freire: «Redes interportuárias nos circuitos do açúcar brasileiro. O trajecto de Gaspar Pacheco, um banqueiro de D. João IV» in CuNHA, Mafalda Soares da (coord.): Do Brasil à Metrópole.., cit., 2001, pp. 15-46.

136 PeDreIRA, Jorge: «Brasil, fronteira de Portugal. Negócio, emigração e mobilidade social (séculos XVII e XVIII)» in CUNHA, Mafalda Soares da (coord.): Do Brasil à Metrópole..., cit., 2001, pp. 47-72.

${ }_{137}$ Cfr. FlORY, Rae \& SMITH, David, «Bahian Merchants and Planters in the Seventeenth and early Eignteenth century", Hispanic America Historical Review, vol. 58 (1978) pp. 571-594.

138 PRESTA, Ana María, Encomienda, familia y negocios en Charcas colonial. Los encomenderos de La Plata 1550-1600, Lima, IEP, 2000.

139 ZÚÑIGA, Jean-Paul : Espagnols d'outre-mer. Emigration, métissage et reproduction sociale à Santiago du Chili, au 17 e siècle, Paris, École des Hautes Études en Sciences Sociales, 2002.

140 MARQues, Guida: «O Estado do Brasil na União Ibérica..., cit., 2002, pp. 7-35.

Hispania, LXIV/1, núm. 216 (2004) 117-156 
a intervenção dos representantes da Coroa. Em diversos momentos os emissários régios afirmavam-se como árbitros de conflitos, adquirindo desse modo um maior ascendente no quadro comunitário. Talvez passe por aqui um dos mais decisivos mecanismos integradores do império português, esse plural aglomerado de territórios, um conjunto cheio de dinamismo e em permanente mutação, com sucessivas incorporações de novas terras e perda de outras.

A um nível que poderíamos apelidar de «constitucional», cumpre ainda ter em conta o impacto exercido pela sucessiva criação de novas unidades políticas na América do Sul. Há que não esquecer que a América Portuguesa, tal como a Espanhola, foi um mundo em permanente ampliação e alargamento, com o desbravamento de novas terras e a incorporação de novas populações indígenas. Para todos os efeitos, a inserção de novas terras e novas gentes nos domínios ultramarinos portugueses significava a entrada de novos membros para o corpo político - já de si pouco homogéneo - do reino. Mas qual era o estatuto desses novos membros? Qual o lugar do Estado do Brasil e dos demais territórios no império: conquista ou herança dinástica? E esse estatuto era imóvel? Pernambuco, por exemplo, depois da vitória contra os neerlandeses, parece afirmar-se como uma região de primeiro plano, e já no século XVIII Rio de Janeiro adquirirá uma centralidade mais forte, substituindo a cidade de São Salvador da Bahia enquanto principal núcleo urbano da América Portuguesa. A este respeito é também importante não esquecer que, desde meados do século XVI, circularam diversas propostas para transferir a corte para o continente sulamericano, e para a fixar algures no Brasil ${ }^{141}$.

\section{FOCOS DE TENSÃO, CONFLITOS E REVOLTAS}

A derradeira secção deste ensaio incide sobre mais uma temática incontornável para quem se dedica ao estudo do Brasil na época dos Habsburgo e dos primeiros Bragança: os movimentos de contestação que se registaram na América Portuguesa ${ }^{142}$.

Como seria de esperar, a imposição de modelos europeus de ordenação comunitária em terras sul-americanas nem sempre suscitou um acolhimento positivo, registando-se, amiúde, rejeições. Tais recusas assumiram diversas configurações, desde a resistência passiva até à revolta aberta e violenta, passando por diversas modalidades de oposição, como a recusa em acatar as ordens ou o boicote às medidas emanadas do centro governativo. Porém, é fundamental distinguir o que esteve de facto na origem de cada uma dessas ocasiões de agitação.

${ }^{141}$ Mello, Evaldo Cabral de: Um imenso Portugal. História e Historiografia, São Paulo, Editora 34, 2002, pp. 35 segs.

${ }_{142}$ Sobre esta temática é fundamental a consulta da obra de Figueiredo, Luciano: Revoltas, fiscalidade e identidade colonial na América portuguesa. Rio de Janeiro, Babia e Minas Gerais, 1640-1671 (tese de doutoramento. 3 vols. São Paulo, USP, 1996).

Hispania, LXIV/1, núm. 216 (2004) 117-156 
É hoje um dado adquirido que alguns desses focos de tensão foram gerados pelo voluntarismo político da Coroa em terras sul-americanas. Tal voluntarismo assumiu várias formas: no final do século XVI e em alguns momentos de Seiscentos os Habsburgo procederam a reformas administrativas, promovendo iniciativas de controle do oficialato local, através de visitas, de devassas e de «residências». Além disso, sob os Habsburgo foram criados novos cargos de governo com um carácter militar muito vincado, tendo sido também delegadas uma série de jurisdições com uma margem de actuação extremamente ampla. $\mathrm{O}$ rei nomeou estes oficiais e colocou-os nos diversos sectores da administração, o que acarretava a inibição dos magistrados ordinários nos casos que se estimava conveniente, bem como a sua substituição por juízes extraordinários designados para o efeito. Apesar dos protestos, esta foi uma frequente manifestação da soberania do monarca, para além de constituir um expediente de vigilância e de controle do próprio oficialato da Coroa.

Como demonstra Guida Marques no seu estudo sobre o Brasil no período em que Portugal esteve agregado à Monarquia Católica, nesse esforço de controle a Coroa não se coibiu em fazer com que órgãos castelhanos - como o Conselho de Estado e o Conselho de Guerra - interviessem directamente no Estado do Brasil, apesar de tal contradizer abertamente o «Estatuto de Tomar» ${ }^{143}$. Como seria de esperar, esta actuação gerou múltiplos conflitos, tanto na Europa como na América do Sul, e não estranha que no epicentro de muitas sedições se encontrem, precisamente, os membros do próprio oficialato da Coroa que se sentiram agravados com a subalternização de que foram objecto.

Além do disciplinamento do oficialato, o voluntarismo régio materializouse, também, numa administração fiscal mais impositiva. De facto, tanto os monarcas Habsburgo como os primeiros Bragança introduziram «novidades» no terreno da fiscalidade, as quais geraram uma proverbial comoção entre as populações. Como seria de esperar, a resposta a estas iniciativas foi, em geral, negativa, traduzindo-se na desobediência às ordens enviadas desde a Europa, na fuga ao fisco e numa fraude fiscal bastante generalizada - fenómenos que, refira-se, não são muito diferentes daqueles que se registaram no reino. A esse respeito recorde-se a dinâmica reformista do tempo do duque de Lerma ${ }^{144}$, ou as novas exacções introduzidas no tempo de Olivares ${ }^{145}$, em especial aquelas que oneravam as transacções de sal e, sobretudo, de açúcar. Como demonstraram os estudos de António de Oliveira ${ }^{146}$, de Fernando Bouza ${ }^{147}$ ou de Jean-

${ }_{143}$ MarqueS, Guida: «O Estado do Brasil na União Ibérica..., cit., 2002, pp. 7-35.

${ }^{144}$ SCHAUB, Jean-Frédéric: «Dinámicas políticas en el Portugal de Felipe III (1598-1621)», Relaciones, 73, 1998, pp. 169-211.

145 Cfr. MARques, Guida: «O Estado do Brasil na União Ibérica..., cit., 2002, pp. 7-35. Para uma comparação com a situação vivida na América Espanhola, cfr. BRONNER, Fred: «La Unión de las Armas en el Perú. Aspectos político-legales», Anuario de Estudios Americanos, 24 (1967) pp. 1133-1176.

146 Oliveira, António de: Poder e oposição politica no periodo filipino (1580-1640), Lisboa, DifeL, 1992; e Movimentos sociais e poder em Portugal no século XVII, Coimbra, Imprensa de Coimbra, 2002.

Hispania, LXIV/1, núm. 216 (2004) 117-156 
Frédéric Schaub ${ }^{148}$, estas e outras iniciativas geraram uma contestação bastante ampla, e as câmaras brasileiras, tal como as suas congéneres do reino, protestaram no momento de pagar novas exacções fiscais. Mais tarde, com o ciclo do ouro, a fiscalidade sobre as transacções ligadas à actividade mineira constituiu também um importante foco de tensão.

Todavia, é importante ter presente que não foi apenas na esfera da administração régia que a presença régia se fez sentir com maior acutilância. A Coroa endureceu a sua posição através do combate ao contrabando, a fim de evitar o «descaminho» do açúcar e, depois, também do tabaco e do ouro ${ }^{149}$. Outra das manifestações mais frequentes de voluntarismo, por parte da Coroa, fez-se sentir ao nível da estrutura militar de defesa, mediante o reforço da hierarquia militar e do sistema das armadas de costa, matérias que levaram oficiais militares da Coroa a imiscuir-se na esfera de actuação de autoridades locais ou regionais, como os capitães -donatários e as câmaras municipais. Dessa intervenção resultaram muitas tensões.

No que concerne às estratégias de resistência contra estas investidas, tradicionalmente a historiografia sempre concedeu mais atenção às explosões de violência. Porém, investigações mais recentes têm revelado que tanto aqueles que sofreram a imposição de modelos europeus de vida comunitária, como aqueles que foram remetidos para lugares subalternos, desenvolveram várias formas de recusa, muitas delas desprovidas de todo e qualquer elemento de violência. É esse, precisamente, o caso da resistência em aceitar os modelos europeus de organização comunitária, ou da proliferação de formas de comportamento desviantes em relação à moral predominante, como por exemplo a magia, a feitiçaria, a sexualidade desregrada, a recusa do modelo familiar europeu, ou o sincretismo religioso ${ }^{150}$.

$\mathrm{E}$ as explosões de violência no contexto das várias revoltas então ocorridas? Qual é o seu sentido? Anti-fiscal? Rejeição de interferências vindas do exterior? Â luz do que sabemos acerca da cultura política daquele tempo, é duvidoso que tais acontecimentos traduzam um anseio de «liberdade» na acepção actual do

\footnotetext{
147 Bouza Álvarez, Fernado: Portugal no Tempo dos Filipes: Política, Cultura, Representações (1580-1668), Lisboa, Cosmos, 2000.

148 SCHAUB, Jean-Frédéric: Le Portugal au temps du comte-duc d'Olivares..., cit., 2001.

${ }_{149}$ HANSON, Carl A.: "Monopoly and contrabando in the Portuguese Tobacco Trade, 16241702», Luzo-Brazilian Review, 19 (1982) pp. 149-168.

${ }^{150}$ Além dos trabalhos já citados de Laura de Mello e SouZA, Luiz MotT e Ronaldo VAINFAS, consulte-se, de FIGUEIREDO, Luciano: $O$ avesso da memória. Cotidiano e trabalbo da mulber em Minas Gerais no século XVIII, Rio de Janeiro, José Olympio Editora, 1993; também de FIGUEIREDO: «O Império em apuros. Notas para o estudo das alteraçōes ultramarinas e das práticas políticas do império colonial português, séculos XVII e XVIII» in FURTADO, Júnia Ferreira (org.): Diálogos Atlânticos. Minas Gerais e as novas abordagens para uma história do Império Ultramarino Português, Belo Horizonte, Humanitas, 2001, pp. 197-254. Veja-se, ainda, de HESPANHA, A. M.: «Revueltas y revoluciones» in La gracia del derecho. Economía de la cultura en la edad moderna, Madrid, Centro de Estudios Constitucionales, 1993, pp. 295-321.
} 
termo. Aliás, é oportuno lembrar que, nas concepções políticas coetâneas, a liberdade, enquanto direito individual, era um valor pouco acalentado. Falavase, sim, em «liberdades» colectivas, usando-se este termo para designar os privilégios e as prerrogativas de um qualquer corpo social ou comunidade ${ }^{151}$. As únicas excepções ao que acabámos de afirmar serão as diversas revoltas protagonizadas por Indígenas e por Africanos. Registadas desde, pelo menos, o último quartel de Quinhentos, estas revoltas foram lideradas por homens e mulheres empenhadas em libertar-se do jugo escravista, e algumas delas foram de tal modo bem sucedidas que originaram os Quilombos, verdadeiras comunidades com uma existência à margem da sociedade colonial ${ }^{152}$. Tais revoltas - e a repressão que se seguiu - foram sem dúvida os momentos em que a face opressiva do domínio colonial se tornou mais visível ${ }^{153}$.

Quanto aos demais motins e sedições que se registaram na América portuguesa nos séculos XVI e XVII, uma boa parte deles possui características muito similares às «alterações» que ocorreram no reino, antes e depois de 1640 . À semelhança do que sucedeu nos domínios europeus dos reis de Portugal, na América do Sul quase todas as sedições foram incentivadas pelos grupos influentes ao nível local, ou seja, por aqueles que eram os únicos verdadeiramente capazes de organizar campanhas de contestação e de descrédito contra ameaças vindas do espaço exterior ao universo polítiço local. No fundo, tais sedições eram uma forma de rejeitar a «novidades» indesejadas, caso dos novos impostos (sobretudo os que incidiam sobre o açúcar) ou da presença de tropa alojada numa povoação à custa dos seus habitantes. As revoltas podiam também ser a expressão da recusa da ingerência de uma autoridade vinda do exterior, por exemplo um comandante militar cuja jurisdição interferia na jurisdição dos oficiais locais.

O tema da ausência do rei era frequentemente evocado no decurso desses momentos de agitação. No discurso do colonato brasílico costumava marcar presença o lamento por o rei se esquecer da sua existência e por relegar os seus domínios americanos para um plano subalterno. Como devemos interpretar estes queixumes? Até que ponto reflectem um efectivo abandono dessas populações? É fundamental responder a estas questões tendo em mente a semelhança entre esse discurso e os queixumes que alguns portugueses dirigiram aos monarcas hispânicos entre 1581 e $1640^{154}$. Cumpre lembrar, também, que em alguns contextos a distância física face ao rei não foi sentida como algo de ne-

${ }^{151}$ Consulte-se, in genere, o excelente livro de COSTA, Pietro: Civitas. Storia della Cittadinanza in Europa, Bari, Laterza, 1999, vol. 1.

152 Sobre este tema, cfr. REIS, João José \& GOMES, Flávio dos Santos (orgs.): Liberdade por um fio. História dos Quilombos no Brasil, São Paulo, Companhia das Letras, 1996.

153 PUNTONI, Pedro: A Mísera Sorte. A Escravidão Africana no Brasil Holandês e as Guerras do Tráfico no Atlântico Sul, 1621-1648, São Paulo, Hucitec, 1999.

154 Sobre esta temática é imprescindível a consulta do excelente estudo de BOUZA ÁlvarEZ, Fernando: «Lisboa Sozinha, Quase Viúva. A Cidade e a Mudança da Corte no Portugal dos Filipes» in Portugal no Tempo dos Filipes., cit., 2000, pp. 159-184.

Hispania, LXIV/1, núm. 216 (2004) 117-156 
gativo, bem pelo contrário, foi tida como uma realidade favorável, pois permitia o aprofundamento da autonomia e o desenvolvimento de mecanismos de auto-regulação ${ }^{155}$. Noutros casos - e como assinalámos a propósito dos trabalhos de Guida Marques -, nota-se até um claro esforço dos membros da sociedade luso-brasileira para se integrarem nos circuitos distributivos do império português, a fim de tirarem partido das oportunidades de carreira e dos recursos proporcionados pelas suas instituições, assim como para beneficiarem das recompensas que o rei concedia àqueles que prestavam serviços à Coroa.

Voltando às revoltas, importa notar que algumas dessas agitações podiam igualmente constituir uma forma de manifestar a exigência do «princípio do indigenato» no provimento dos ofícios; o chamado «discurso nativista» que reivindicava que todos os cargos da governança fossem reservados para a «nobreza da terra». Uma vez mais, contudo, este fenómeno não é exclusivo do Brasil, sendo possível encontrar reivindicações similares nas comunidades locais da Europa e, também, por toda a América Espanhola. Acresce que a distinção entre reinóis e naturais do Brasil nem sempre era nítida. Michel Bertrand, num estudo recente sobre os oficiais da fazenda do México, questionou a clássica oposição entre "criollos» e "gachupines» (ou "peninsulares»), mostrando que a fronteira entre esses dois grupos era frequentemente pouco clara, até porque muitos dos reinóis acabavam por ficar rapidamente integrados no meio «criollo» ${ }^{156}$. Em face das pesquisas até agora realizadas, dir-se-ia que na América Portuguesa se passaria algo de semelhante, embora esta temática careça ainda de uma investigação sistemática, na linha, por exemplo, dos estudos de Evaldo Cabral de Mello sobre o uso político de expressões como «filhos da terra» ou «nobreza da terra», mas também de termos como «mazombo", «reinol» ou «mascate» ${ }^{157}$.

Por outro lado, é bem possível que o facto de o território sul-americano se caracterizar por uma maior indefinição jurisdicional tenha estado na origem de alguns dos conflitos então registados. A circunstância de se tratar de territórios recém-incorporados nos domínios da Coroa portuguesa também motivou muitos conflitos. Se na.Europa nem sempre era clara a partilha de competências governativas e administrativas, imagine-se o que seria a situação no Brasil, um vastíssimo território onde a administração "à Europeia" estava a dar os seus primeiros passos. Como é bem sabido, tanto no centro da monarquia como nos

iss Cfr. o estudo de Bertrand, Michel sobre o Vice-reinado da Nova Espanha nos séculos XVII e XVIII, no volume de CASTEllano, Juan Luis, e DeDIEU, Jean-Pierre (orgs.), Réseaux, familles et pouvoirs dans le monde ibérique à la fin de lAncien Régime, Paris, CNRS Éditions, 1998.

${ }^{156}$ BERTRAND, Michel: Grandeur et misère de loffice. Les officiers de finances de Nouvelle-Espagne (XVIIe-XVIIIe siècles), Paris, Publications de la Sorbonne, 1999.

157 Acerca deste tema, importa consultar o estudo de BICALHO, Maria Fernanda, «Elites coloniais: a Nobreza da Terra e o governo das conquistas. História e Historiografia» in MONTEIRO, Nuno G., Cunha, Mafalda Soares da, e CARDim, Pedro (orgs.): Optima Pars. As Elites do Antigo Regime no espaço Ibero-americano, Lisboa, Imprensa de Ciências' Sociais (no prelo).

Hispania, LXIV/1, núm. 216 (2004) 117-156 
territórios ultramarinos era muito frequente a concorrência - e a tensão - entre os vários órgãos da Coroa que ambicionavam ter uma palavra a dizer na tramitação dos assuntos administrativos relativos ao Brasil. Assim, na documentação coetânea é muito fácil encontrar conflitos de competência envolvendo órgãos como o Conselho da Fazenda, o Conselho da Índia, a Junta da Fazenda do Brasil, a Junta de Pernambuco, o Conselho Ultramarino, a Companhia do Comércio do Brasil, a Junta do Tabaco, para já não falar dos tribunais, órgãos que também costumavam intervir nessas contendas.

Não devemos esquecer que a introdução do conceito Ocidental de «justiça» e de "administração" se traduziu, sobretudo, na imposição de um modelo organizativo completamente estranho ao babitat americano. Enquanto que na Europa a noção Ocidental de «justiça» e de «governo» estavam profundamente enraizadas em tradições multisseculares, na América do Sul, pelo contrário, o ambiente era muito mais mutável, o que concedia mais espaço para a introdução de «novidades» e de cambiantes na dinâmica política.

Podemos assim dizer que a inexistência de jurisdições prévias proporcionou mais espaço à Coroa para recorrer a expedientes administrativos mais ágeis, caso dos já citados juízes delegados ou de comissão ${ }^{158}$. Como já assinalámos, em diversos momentos do século XVII a Coroa procurou apertar o seu dispositivo administrativo em terras sul-americanas. Tal empenho traduziu-se numa série de reformas, entre as quais se destacam aquelas que foram empreendidas sob os Habsburgo, mas também na segunda metade de Seiscentos, período em que se assistiu à chamada "Guerra dos Bárbaros», ou seja, o esforço para submeter politicamente as populações indígenas do interior nordestino ${ }^{159}$. Quanto ao conjunto de medidas que visaram circunscrever o autonomismo paulista, também devem ser encaradas como um sinal do reforço do quadro administrativo da Coroa em terras sul-americanas ${ }^{160}$. Aliás, o exemplo de São Paulo e da sua progressiva incorporação no dispositivo da Coroa tem paralelos com o que se passou em outras cidades, como o Rio de Janeiro, Salvador da Bahia ou Olinda.

Como não podia deixar de ser, este incremento da faceta imperativa da Coroa gerou tensões, reacções de recusa e revolta. Antes de mais porque estas iniciativas atingiram as tradições autonomistas que as várias cidades brasileiras tinham desenvolvido. Para Luiz Felipe de Alencastro, foram quatro os principais movimentos de defesa dessas autonomias sul-americanas: em São Paulo, em 1654, no contexto do movimento anti-jesuítico e anti-metropolitano em prol do cativeiro de indígenas; no Pará e no Maranhão, em 1654, no conflito

158 Cfr. Melıo, Evaldo Cabral de: A Fronda dos Mazombos. Nobres contra Mascates, São Paulo, Companhia das Letras, 1995; e HespanHA, António Manuel: "A constituição do Império português..., cit., pp. 175 segs.

159 Veja-se maxime PUNTONI, Pedro: A Guerra dos Bárbaros..., cit., 2000.

160 RuIZ GonZÁLEZ, Rafael: $A$ vila de São Paulo durante a uniäo das coroas: estratégias políticas e transformações jurídicas, Tese defendida na Universidade de São Paulo, São Paulo, 2002; SilvA, Janice Theodoro da: São Paulo 1554-1880. Discurso ideológico e organização espacial, São Paulo, Moderna, 1988.

Hispania, LXIV/1, núm. 216 (2004) 117-156 
dos moradores com os jesuítas e as autoridades régias sobre a gestão do trabalho indígena; na serra de Ibiapaba (Ceará), apontada como antro de índios apóstatas, após a ocupação neerlandesa; em Palmares, no ano de $1694^{161}$. A estes episódios haverá que juntar o caso Pernambucano, especial pela sua repercussão e exemplarmente estudado por Evaldo Cabral de Mello ${ }^{162}$.

Contudo, é imprescindível notar que, na sua maioria, estas revoltas foram actos localizados, desprovidos de uma dimensão programática consistente e com pouca ou nenhuma articulação entre si. A este respeito, só no final de Setecentos é que o cenário muda, uma vez que terá sido nessa altura que surgiram as primeiras movimentações com outra escala e servidas por programas mais amplos ${ }^{163}$. Por outro lado, é igualmente importante não perder de vista o sentido eminentemente conservador das revoltas registadas em finais do século XVI e durante todo o período de Seiscentos - delas estiveram quase ausentes programas consistentes de ruptura ou de criação de um novo quadro constitucional, por exemplo de cariz republicano. De resto, talvez resida aí uma das explicações para o facto de o rei perdoar tão frequentemente os revoltosos. $\mathrm{Na}$ realidade, a punição dos cabecilhas das revoltas foi, de um modo geral, muito benévola, o que sugere que a Coroa, face a estas revoltas, ao invés de levar a cabo uma repressão dura e violenta, apostou em formas "doces" de reposição da ordem e de regresso à "paz social" 164 .

Neste campo de estudo sobre a resistência dos luso-brasileiros às iniciativas régias torna-se esclarecedor olhar, também, para outras formas de oposição, menos visíveis mas porventura mais eficazes do que as revoltas. Estas, pelo ruído que geravam, sempre polarizaram a atenção dos historiadores, fazendo-os esquecer outras modalidades de contestação, como era o caso da passividade ante os ataques de forças inimigas. Tal aconteceu em certos momentos das guerras contra os neerlandeses ${ }^{165}$, mas também em ocasiões posteriores, como por exemplo no saque que as forças francesas realizaram no Rio de Janeiro, logo no início de Setecentos. Nessa ocasião, a guarnição não ofereceu resistência, atitude que, segundo Maria Fernanda Bicalho, deve ser interpretada como uma forma de contestar a autoridade de Lisboa ${ }^{166}$. As delongas na aplicação das decisões régias eram também uma forma habitual de resistência, o mesmo se

161 AlenCastro, Luiz Felipe de: O Trato dos Viventes..., cit., 2001, pp. 343 segs.

162 Para além das obras já citadas de Evaldo Cabral de MelloO, consulte-se igualmente $A$ Fronda dos Mazombos..., cit., 1995.

163 JANCSÓ, Istvan: «Peças de um mosaico, ou apontamentos para o estudo da emergência da identidade nacional brasileira", Revista de História das Ideias, vol. 21 (2000) pp. 389-440.

164 Sobre este tema é fundamental a consulta de MONTEIRO, Rodrigo Bentes: $O$ Rei no Espelho. $A$ Monarquia Portuguesa e a colonização da América, 1640-1720, São Paulo, Hucitec, 2002, pp. 231 segs.

165 Ferlini, Veria Lucia Amaral : «Resistência e acomodação. Os Holandeses em Pernambuco (1630-1640)" in ThOMAs, Werner, e DE Groof, Bart (orgs.): Rebelión y resistencia en el mundo bispánico del siglo XVII, Lovaina, Leuven University Press, 1992, p. 227-249.

166 BICALHO, Maria Fernanda: A Cidade e o Império..., cit., 2003, pp. 268 segs. 
podendo dizer do boicote à acção dos representantes da Coroa, ou da recusa em fornecer a informação solicitada pelo poder régio ${ }^{167}$.

Por fim, importa lembrar um outro ponto já discutido nas páginas antecedentes: até meados do século XVIII o dispositivo político-administrativo da Coroa foi relativamente pouco impositivo, um dado que sem dúvida retira força explicativa àqueles que sempre encararam as sedições como movimentos de protesto e de rejeição de um poder colonial opressivo. Não se trata de afirmar que o colonialismo português não foi violento - é evidente que foi violento $\mathrm{e}$ tão opressivo quanto os demais dispositivos coloniais europeus da época moderna. Porém, importa ter em conta que o caso português possui alguma singularidade, pois os métodos de controle desenvolvidos pela Coroa parecem ter passado não tanto pela implementação de um pesado e opressivo dispositivo de dominação colonial, mas sim, e em vez disso, pela imposição de modelos europeus de organização social, imposição essa efectuada com a cumplicidade do colonato e em estreita articulação com a Igreja. Além disso, em geral tal imposição decorreu num quadro que procurava garantir aos influentes locais uma margem bastante razoável de autonomia.

Por último, e como já sugerimos, é preciso não esquecer que, a par destas movimentações contestatárias, a história da dominação colonial que a Coroa exerceu na América do Sul apresenta, também, muitos exemplos que apontam no sentido da integração. Estudos recentes demonstraram que essa dinâmica integradora esteve presente no espaço brasileiro mesmo nos últimos tempos do "Antigo Sistema Colonial». No fundo, estas e as demais questões que foram afloradas obrigam a repensar os termos em que habitualmente se encara a história ibero-americana dos séculos XVI a XVIII. Talvez seja necessário pôr de lado a tradicional relação bipolar metrópole/colónia, colonizador/colono, integração/revolta, dominador/dependente, porque - como vimos - ela não capta muitos dos mais fundamentais aspectos do relacionamento entre as Coroas ibéricas e os seus territórios sul-americanos, muito díspares entre si e portadores de uma identidade bastante vincada. Como recentemente propôs Maria Fernanda Bicalho ${ }^{168}$, torna-se necessário repensar os termos da relação entre o reino e os territórios sul-americanos, superando os binómios ordem/desordem, obediência/insubmissão, e encarando essa relação como um processo muito mais complexo, uma constante negociação geradora de uma relação onde ordem e insubmissão coexistem, onde a parte sul-americana, longe de ser um agente passivo, responde activamente e de forma criativa à imposição de modelos europeus de dominação, interagindo com o reino e, muitas vezes, tirando partido dos recursos disponibilizados pela Coroa.

167 Cfr. Hespanha, António Manuel: «Sabios y rústicos. La dulce violencia de la razón jurídica» in La gracia del derecho. Economía de la cultura en la edad moderna, Madrid, Centro de Estudios Constitucionales, 1993, pp. 17-60.

168 BICALHO, Maria Fernanda: «Centro e Periferia: pacto e negociação política na administração do Brasil colonial», Leituras. Revista da Biblioteca Nacional, 6 (Primavera de 2000) pp. 17-40.

Hispania, LXIV/1, núm. 216 (2004) 117-156 